\title{
Final Report on the Analytical Results for Tank Farm Samples in Support of Salt Disullison Evaluation
}

by

D. T. Hobbs

Westinghouse Savannah River Company

Savannah River Site

Aiken, South Carolina 29808

$$
\text { not a conf }
$$

A document prepared for TANK FOCUS AREA MID-YEAR REVIEW at Salt Lake City; UT, USA from - .

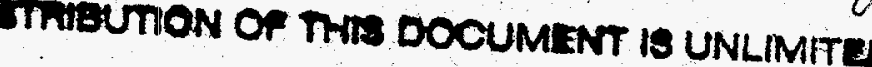

DOE Contract No. DE-AC09-96SR18500

This paper was prepared in connection with work done under the above contract number with the U. S. Department of Energy. By acceptance of this paper, the publisher and/or recipient acknowledges the U.S. Government's right to retain a nonexclusive, royalty-free license in and to any copyright covering this paper, along with the right to reproduce and to authorize others to reproduce all or part of the copyrighted paper. 


\section{DISCLAIMER}

This report was prepared as an account of work sponsored by an agency of the United States Government. Neither the United States Government nor any agency thereof, nor any of their employees, makes any warranty, express or implied, or assumes any legal liability or responsibility for the accuracy, completeness, or usefulness of any information, apparatus, product, or process disclosed, or represents that its use would not infringe privately owned rights. Reference herein to any specific commercial product, process, or service by trade name, trademark, manufacturer, or otherwise does not necessarily constitute or imply its endorsement, recommendation, or favoring by the United States Government or any agency thereof. The views and opinions of authors expressed herein do not necessarily state or reflect those of the United States Government or any agency thereof.

This report has been reproduced directly from the best available copy.

Available to DOE and DOE contractors from the Office of Scientific and Technical Information, P.O. Box 62, Oak Ridge, TN 37831; prices available from (615) 576-8401.

Available to the public from the National Technical Information Service, U.S. Department of Commerce, 5285 Port Royal Road, Springfield, VA 22161. 


\section{DISCLAIMER}

Portions of this document may be illegible electronic image products. Images are produced from the best available original document. 
DATE: December 12, 1996

TO: $\quad$ S. D. Fink, 773-A<smiles>CCCC1(C)CCCCC1</smiles>

FROM: D. T. Hobbs, 773-A

Final Report on the Analytical Results for Tank Farm Samples in Support of Salt Dissolution Evaluations (U)

\section{SUMMARY}

Recent processing of dilute solutions through the $2 \mathrm{H}$-Evaporator system caused dissolution of salt in Tank $38 \mathrm{H}$, the concentrate receipt tank. This report documents analytical results for samples HTF-001, HTF-002, HTF-003, HTF-004 and ITP-309, taken from this evaporator system: The results indicate the following:

- the presence of significant quantities of insoluble species (i.e., sodium, iron, chromium and manganese) to mitigate concerns of nuclear criticality safety,

- the composition of the Tank 41 saltcake sample is similar to previously analyzed samples taken in 1993, and

- neptunium-237 concentrations in the liquid phases of the Tank $43 \mathrm{H}$ and Tank $38 \mathrm{H}$ samples and the soluble salt fraction of the Tank 41 saltcake sample are sufficiently high such that the Saltstone limit for neptunium-237 concentration in the decontaminated salt solution may be exceeded if these wastes were processed in a single In-Tank Precipitation batch.

\section{INTRODUCTION}

Recent operations in the $2 \mathrm{H}$-Evaporator system resulted in the dissolution of salt in Tank $38 \mathrm{H}$. At the request of High-Level Waste Engineering, SRTC analyzed samples from three tanks to provide data confirming the presence of sufficient neutron poisons associated with the fissile material contained in the undissolved solids [1]. The samples consisted of two variable depth samples (VDS) from Tank 38H (HTF-001 and HTF-004), one saltcake sample from Tank 38H (HTF-003), one VDS from Tank 43H (HTF-002) and one saltcake sample from Tank $41 \mathrm{H}$ (TTP-309).

\section{EXPERIMENTAL}

The following five samples were received and analyzed at SRTC. To ensure the presence of neutron poisons during storage and processing of the wastes in these tanks, the actinide and metals content were determined in the as-received sample, in the individual solid and liquid fractions after performing a solid-liquid separation and in the insoluble solids fraction after removing residual intersitial liquid and soluble salts by washing.

\begin{tabular}{llll} 
Sample ID & Tank & Type & \multicolumn{1}{c}{ Description } \\
\hline HTF-001 & $38 \mathrm{H}$ & VDS & entrained sludge/supernate mix taken 6" above salt \\
HTF-002 & $43 \mathrm{H}$ & VDS & sludge/supernate mix taken at eductor suction \\
HTF-003 & $38 \mathrm{H}$ & Saltcake & salt taken at salt supernate interface \\
HTF-004 & $38 \mathrm{H}$ & VDS & entrained sludge/supernate mix at salt interface \\
ITP-309 & $41 \mathrm{H}$ & Saltcake & salt from eductor well after removal of jet
\end{tabular}

a Preliminary results for this sample identified as $41 \mathrm{SC} 0696$ were reported in reference 10.

${ }^{b}$ See reference 11 fot further details on the Tank $38 \mathrm{H}$ samples. 
The samples were placed into the Shielded Cells in 773-A and prepared for analysis.

Details of the preparation methods are described below.

\section{VDS Sample HTF-001}

This sample was originally sent to Analytical Laborateries in $772-\mathrm{F}$ for determination of corrosion chemistry. Visual inspection of the sample in $772-\mathrm{F}$ revealed the presence of sludge solids. The sample was filtered in $772-\mathrm{F}$ to separate the solid and liquid phases. The solids were recovered from the filter, returned to the sample bottle and transported to SRTC for analysis.

\section{VDS Samples HTF-002 and HTF-004}

Three subsamples were taken from the as-received slurry samples, dried for 48 hours at $100^{\circ} \mathrm{C}$ and dissolved in aqua regia. The aqua regia dissolutions were diluted to $100 \mathrm{~mL}$ and aliquots analyzed for actinides and metals contents.

Forty milliliters of each slurry sample were placed in a glass centrifuge tube. The tubes were centrifuged for two hours at which time no further settling was observed visually. The supernatant liquid was decanted from the solids. Duplicate portions of the supernatant liquid were diluted into $2 \mathrm{M}$ nitric acid and analyzed for actinides and metals contents. The settled solids were rinsed twice with $0.015 \mathrm{M}$ sodium hydroxide solution. After centrifuging for 30 minutes, the rinse solutions were decanted from the settled solids. The rinse solutions were combined, diluted into $2 \mathrm{M}$ nitric acid and analyzed for actinides and metals contents. The settled solids were dried for 48 hours at $100^{\circ} \mathrm{C}$. A subsample of the settle solids was dissolved in aqua regia. The aqua regia dissolutions were diluted to 250 $\mathrm{mL}$ and aliquots analyzed for actinides and metals contents.

Between 5.0 and 10.0 grams of the solids isolated from above were washed with one 25 $\mathrm{mL}$ and two $5 \mathrm{~mL}$ portions of $0.015 \mathrm{M}$ sodium hydroxide solution to remove any residual water soluble salts. After centrifuging, the liquid phase was decanted from the solids. All of the decanted wash water was combined and analyzed for actinides and metals contents. The remaining solids were dried at $100^{\circ} \mathrm{C}$. Between 2.0 and 2.5 grams of the washed and dried solids were dissolved in aqua regia and analyzed for actinides and metals contents.

The remainder of the partially washed solids were washed with one $25 \mathrm{~mL}$ portion and two $10 \mathrm{~mL}$ portions of inhibited water. After centrifuging, the wash waters were decanted off and discarced. The undissolved solids were dried at $100^{\circ} \mathrm{C}$ overnight. Subsamples were analyzed for total inorganic and organic carbon, presence of crystalline phases by $x$-ray diffraction analysis and particle morphology, particle size and elemental composition by scanning electron microscopy. A portion of the insoluble solids were also dissolved in concentrated hydrochloric acid and analyzed for anions by ion chromatography (IC).

\section{Saltcake Samples HTE-003 and ITP-309 (41 SC0696)}

Approximately 10 grams of the as-received samples were dried at $100^{\circ} \mathrm{C}$. Three subsamples of the dried saltcake from each sample were dissolved in aqua regia. The aqua regia dissolutions were diluted to $100 \mathrm{~mL}$ and aliquots analyzed for actinides and metals contents.

Approximately ten grams of each damp saltcake sample were placed in duplicate glass centrifuge tubes. Twenty-five milliliters of $0.015 \mathrm{M}$ sodium hydroxide solution were added to each tube and the contents shaken. The samples were centifuged for one hour. The supernatant liquid was decanted from the settled solids into a clean polyethylene (PE) bottle. Aliquots of the supernatant liquid were diluted into $2 \mathrm{M}$ nitric acid and analyzed for actinides and metals content. The settled solids were contacted in a similar manner two more times with approximately $5 \mathrm{~mL}$ of $0.015 \mathrm{M}$ sodium hydroxide solution. Each rinse 
more times with approximately $5 \mathrm{~mL}$ of $0.015 \mathrm{M}$ sodium hydroxide solution. Each rinse was diluted into $2 \mathrm{M}$ nitric acid solution and analyzed for actinides and metals contents. The remaining solids were dried at $100^{\circ} \mathrm{C}$ and dissolved in aqua regia. The aqua regia dissolutions were diluted to $100 \mathrm{~mL}$ and aliquots analyzed for actinides and metals contents.

\section{Analytical Methods}

Each sample was analyzed for the following: (1) specific gravity, (2) total uranium using a kinetic phosphoresence method referred to as Chemchek, (3) selected metallic and nonmetallic elements by inductively coupled plasma emission spectroscopy (ICP-ES) and (4) uranium and plutonium isotopes by inductively coupled plasma mass spectrometry (ICP-MS). Aqua regia blank and nitric acid blank samples analyzed with each set of samples. A uranium and metals standard was prepared by dissolving a measured quantity of previously characterized powdered glass in aqua regial [2]. Analytical results were corrected for the measured responses of the acid solution blanks and the glass standard. The insoluble solids fractions of HTF-002 and HTF-004. were also analyzed by alpha and gamma spectroscopy for plutonium-238 and americium-241, respectively, as well as total inorganic carbon (TIC), total organic carbon (TOC), scanning electon microscopic (SEM) and $\mathrm{x}$-ray diffraction (XRD).

\section{RESULTS AND DISCUSSION}

Appendices 1-5 contain a compilation of all ICP-ES, ICP-MS, alpha spectroscopy and gamma spectroscopy results and calculated weight ratios for each of the five samples. Results are provided for the as-received sample, the liquid and solids fractions for each VDS slurry sample, the soluble salt fraction for each saltcake sample and the insoluble solids fraction of the VDS slurry and saltcake samples.

Table I presents the analytical results for the two as-received VDS samples (HTF-002 \& HTF-004) and the two as-received salt samples (HTF-003 and ITP-309). The reported concentrations use a dry solids basis. For all samples, the weight ratio of neutron poisons to equivalent fissile uranium is sufficient to mitigate concems of nuclear criticality safety. The high chromium concentration in the as-received Tank 38H VDS sample results from a high chromium concentration in the liquid phase. After removing the liquid phase from the VDS samples, the chromium concentration in the solids fraction is below that of iron (see Table II).

A solid-liquid separation of the VDS samples was performed so that the actinides and metals content could be determined in the solid fraction of the slurry. The resulting solids would represent the layer of settled solids for the waste tanks conditions including the $2 \mathrm{H}$ Evaporator under current operating conditions. Table II gives the analytical results for the solids fraction of the three VDS samples. As in the case of the as-received samples, the concentrations of neutron poisons relative to the equivalent fissile uranium concentration is sufficient to mitigate concerns of nuclear criticality safety.

Good agreement was observed for the two Tank 38H VDS samples with the exception of manganese. Manganese is most likely present as manganese dioxide, a black or brown/black solid sparingly soluble in alkaline solutions. The presence of this compound may explain the much darker appearance of the earlier VDS sample (HTF-001) compared to the later sample (HTF-004).

The solids fraction of the Tank 43H VDS sample had much higher uranium, plutonium, iron, chromium and manganese content than the Tank $38 \mathrm{H}$ samples (see Table II). The sodium content was also lower for the Tank $43 \mathrm{H}$ sample compared to the Tank $38 \mathrm{H}$ samples. These results suggest that the Tank $43 \mathrm{H}$ sample contains a higher sludge 
fraction, which is expected since Tank $43 \mathrm{H}$ is the H-Area low activity fresh waste receipt tank. High $\mathrm{Na} / \mathrm{U}, \mathrm{Fe} / \mathrm{U}, \mathrm{Cr} / \mathrm{U}$ and $\mathrm{Mn} / \mathrm{U}$ weight ratios were observed for all three solids fractions in the VDS samples. Relative to the as-received sample results, the $\mathrm{Na} / \mathrm{U}$ ratios decrease, but all others increase. This trend is expected. As the solids settle, liquid is displaced which is high in $\mathrm{Na}$ due to the presence of sodium salts, but low in $\mathrm{Fe}, \mathrm{Cr}$ and Mn. Sodium remains high in the solids fraction due to the presence of undissolved salt. Undissolved salt in the second Tank 38H VDS sample is suspected due to the lighter color compared to typical sludge samples.

The compositions of the water-soluble and water-insoluble fractions of the two salt samples (HTF-003 and ITP-309) were also determined. Table III presents the results for the waterinsoluble fractions. The results for the water-soluble fraction of the saltcake samples are provided in Appendices 3 and 5. The insoluble solids represent that fraction of the waste in the tank that would remain undissolved upon addition of dilute liquids to these tanks. These additions produce the greatest possible concentrating mechanism for actinides. On a mass basis, the actinide content is higher for these solids than that of the as-received samples or the solids separated from the VDS samples. However, appreciable quantities of neutron poisons $\mathrm{Na}, \mathrm{Fe}, \mathrm{Cr}$ and $\mathrm{Mn}$ (Tank $38 \mathrm{H}$ only) remain in the water-insoluble solids.

The composition of the insoluble solids fraction of the two VDS samples, HTF-002 and HTF-004) were also determined as presented in Table IV. There was insufficient sample to perform the same analyses on the other Tank 38H VDS sample, HTF-001. For both samples, there are sufficient concentrations of neutron poisons to mitigate concerns of nuclear criticality safety. Results indicate a higher actinide concentration for the Tank $43 \mathrm{H}$ sample compared to the Tank $38 \mathrm{H}$ sample. The higher actinide concentration in Tank $43 \mathrm{H}$ also suggests a higher fraction of sludge solids in this tank versus that in Tank 38H.

In principle, the results for the insoluble solids fraction of the Tank 38H VDS (HTF-004) and saltcake (HTF-003) samples should be similar. The relative abundance of the uranium and plutonium isotopes are very similar for both samples indicating that the uranium and plutonium is from a similar source. However, the actinides and other metals concentrations are significantly different. The saltcake sample showed higher actinide and metals concentrations which suggests the insoluble solids in the saltcake sample are comprised of a higher fraction of Separations Canyon sludge waste than the VDS sample. Other insoluble solids could arise from solid phases produced during and after evaporation and from other waste generators (e.g., Receipt Basin for Offsite Fuels, 299-H Decontamination Facility and Defense Waste Processing Facility).

Total inorganic and organic carbon analysis of the solids indicated a relatively high organic carbon content in the insoluble solids. The SEM analyses of solids for particle morphology and elemental composition indicated no evidence of spherical shaped material ion-exchange resin beads. The HTF-002 sample was comprised of aggregates of irregularly shaped solids comprised of $\mathrm{Fe}, \mathrm{Mn}, \mathrm{Ca}$, Si, $\mathrm{Al}, \mathrm{Na}$, $\mathrm{Cr}$. The HTF-004 sample was comprised of aggregates of irregularly and cubic shaped solids comprised of $\mathrm{Na}, \mathrm{Si}, \mathrm{Al}, \mathrm{Ca}, \mathrm{Cr}$ and $\mathrm{Fe}$.

Semi-volatile organic analysis (SVOA) using gas chromatography-mass spectrometry detected no extractable organic compounds [5]. Portions of the insoluble solids were dissolved in concentrated hydrochloric acid and analyzed by ion chromatography and TOC. Hydrochloric acid was chosen to minimize the oxidation of the organic compounds present in the samples. Formate and oxalate were detected in both samples. However, as a result of the poor reproducibility of replicate measurements for formate, oxalate, and other analytes (e.g., nitrate and phosphate), quantification of the formate and oxalate content was not possible. It is recommended that further development be undertaken to improve anaytical methods for the determination of organic compounds in high-level waste samples. 


$\begin{array}{llll}\text { Sample ID } & \text { Tank } & \text { TIC } & \text { TOC } \\ \text { HTF-002 } & 43 \mathrm{H} & 3450 & 18600 \\ \text { HTF-004 } & 38 \mathrm{H} & .3100 & 9200\end{array}$

XRD analysis of the HTF-002 (Tank 43H) and HTF-004 (Tank 38H) insoluble solids revealed the presence of sodium salts of carbonate, oxalate, nitrate and aluminate silicate. A list of the crystalline phases for both samples are provided below.

\begin{tabular}{lll} 
Sample ID & Tank & Cystalline Phases Identified by XRD \\
\hline $\mathrm{HTF}-002$ & $43 \mathrm{H}$ & \\
& & $\mathrm{Na}_{2} \mathrm{C}_{2} \mathrm{O}_{4}$ \\
& & \\
$\mathrm{HTF}-004$ & $\left.38 \mathrm{H} \mathrm{Si}_{6} \mathrm{O}_{24}\right)\left(\mathrm{NO}_{3}\right)_{2} 4 \mathrm{H}_{2} \mathrm{O}$ \\
& & $\mathrm{Na}_{2} \mathrm{CO}_{3} \mathrm{H}_{2} \mathrm{O}$ \\
& $\mathrm{Na}_{2} \mathrm{C}_{2} \mathrm{O}_{4}$ \\
& $\mathrm{NaNO}_{3}$ \\
& $\mathrm{Na}_{8}\left(\mathrm{Al}_{6} \mathrm{Si}_{6} \mathrm{O}_{24}\right)\left(\mathrm{NO}_{3}\right)_{2} 4 \mathrm{H}_{2} \mathrm{O}$
\end{tabular}

Analytical results for the liquid fraction of the Tank $43 \mathrm{H}$ (HTF-002) and Tank $38 \mathrm{H}$ (HTF004) VDS samples are provided in Appendices $2 \mathrm{~A}$ and $4 \mathrm{~A}$. Comparison of the results indicated the liquid phases in both tank samples are very similar in metals and actinide composition and actinide isotopics. Comparison of the hydroxide, nitrate and other anionic species contents is not possible as neither sample was analyzed for these type of components. Neptunium-237 concentrations in both samples are high enough to be a concern for disposal in Saltstone. After correcting for dilution to a sodium ion concentration of 5.0 molar (target In-Tank Precipitation (ITP) feed concentration) and assuming no removal during ITP processing, the neptunium-237 concentrations are about a factor of 3 higher than that allowed in Saltstone feed[6]. Thus, the liquid fraction of the waste in Tank $43 \mathrm{H}$ and $38 \mathrm{H}$ should not be processed in a single ITP batch.

Analytical results for the soluble salt fractions of the two saltcake samples, Tank $38 \mathrm{H}$ (HTF-003) and Tank 41H (ITP-309)), are presented in Appendices 3A and 5A. These results are based on the as-received saltcake and, therefore, include interstitial liquid. Tank $41 \mathrm{H}$ saltcake contained a higher concentration of insoluble solids than Tank $38 \mathrm{H}$ saltcake. The insoluble solids content for Tank $41 \mathrm{H}$ is consistent with that found in previous Tank $41 \mathrm{H}$ saltcake samples $(0.52-1.7 \mathrm{wt} \%)[7]$.

$\begin{array}{ccc} & \begin{array}{l}\text { Tank 38H } \\ (\mathrm{HTF}-003)\end{array} & \begin{array}{c}\text { Tank 41H } \\ \text { (ITP-309) }\end{array} \\ \text { wt } \% \text { insoluble solids } & 0.493 \pm 0.0035 & 1.39 \pm 0.28\end{array}$

The two saltcake samples were similar in aluminum, sodium, uranium and plutonium content. Tank $41 \mathrm{H}$ contained much higher concentrations of chromium and phosphorus as well as higher concentrations of uranium-235 and equivalent fissile uranium. The neptunium-237 content in the Tank $38 \mathrm{H}$ sample is such that upon dissolution to produce a 5.0 molar sodium ion salt solution, the neptunium-237 concentration would be below the Saltstone feed requirement of $0.03 \mathrm{nCi} / \mathrm{g}$. For the Tank $41 \mathrm{H}$ saltcake sample, the neptunium-237 concentration is such that the resulting salt solution would have a neptunium-237 concentration of $0.045 \mathrm{nCV} / \mathrm{g}$, which exceeds the Saltstone feed . requirement. 
S. D. Fink

WSRC-TR-96-0410, rev. 0

December 12, 1996

Page 6 of 22

Sodium, aluminum and phoshorous concentrations in this Tank $41 \mathrm{H}$ saltcake sample are similar to those determined in previous Tank $41 \mathrm{H}$ saltcake samples [7]. The uranium and plutonium content as well as the isotopic abundances for uranium-235 and uranium-238 are within the.range of values determined for the previous samples $[7,8]$.

QUALITY ASSURANCE

All results reported in this document obtained in accordance with the requirements outlined in the technical task and quality assurance plans governing this work $[3,4]$. Results recorded in laboratory notebook, WSRC-NB-96-694.

REFERENCES

1. Technical Task Request HLE-TTR-97-003, "Tank 38 Salt Analysis to Determine Neutron Poisons," October 9, 1996.

2. C. J. Coleman, N. E. Bibler \& R. A. Dewberry, "Analyses of High-Level Radioactive Sludges and Glasses at the Savannah River Site," Proceedings of the Symposium on Waste Management at Tucson, Arizona, February 25 - March 1, 1990, Volume II, pages 651-658.

3. D. T. Hobbs, "Technical Task Plan for The Analysis of Tank Farm Samples in Support of Salt Dissolution Evaluations (U),"WSRC-RP-96-526, revision 0, October 13, 1996.

4. D. T. Hobbs, "Task Quality Assurance Plan for the Analysis of Tank Farm Samples in Support of Salt Dissolution Studies (U)," WSRC-RP-96-0527, rev. 0, October 13, 1996.

5. S. Crump, memo to D. T. Hobbs, "GC/MS Analytical Support - Semivolatiles (U)," SRT-ADS-96-0470, December 12,1996. A copy of this memo is recorded on page 100 of laboratory notebook WSRC-NB-96-694.

6. WSRC 241-82H Control Room Process Requirements (U), WSRC-RM-91-63, revision 15, October, 1996.

7. D. T. Hobbs, "Final Report: Analysis of Tank 41H Saltcake Sample \#2 and Comparison to Sample \#1 (U)," WSRC-TR-94-057, January 26, 1994.

8. D. T. Hobbs and C. J. Coleman, "Analysis of Tank $41 \mathrm{H}$ Saltcake Sample (U)," WSRC- RP-93-729, May 12, 1993.

9. R. H. Ross, "Nuclear Criticality Safety Evaluation - Minimum Safe Ratios of Inherent Saltcake Metals to Uranium," N-NCS-H-00034, October 14, 1996.

10. D. T. Hobbs, "Preliminary Analytical Results for Tank Farm Samples in Supoort of Salt Dissolution Evaluations (U)," WSRC-RP-96-544, revision 0, October 21, 1996.

11. R. H. Ross, "Nuclear Criticality Safety Assessment for Tank 38H Salt Dissolution," WSRC-TR-96-0336, revision 1, December 23, 1996. 
Table I. Analytical Results for As-Received VDS and Salt Samples

\begin{tabular}{|c|c|c|c|c|c|c|c|c|}
\hline & $\begin{array}{c}\text { HTF-004 } \\
\text { Tk 38H } \\
\text { VDS } \\
\text { Average } \\
(\mu \mathrm{g} / \mathrm{g})\end{array}$ & $\begin{array}{c}\text { Sid. Dev. } \\
(\mu \mathrm{g} / \mathrm{g})\end{array}$ & $\begin{array}{c}\text { HTF-003 } \\
\text { Tk 38H } \\
\text { Salt } \\
\text { Áveraye } \\
\text { ( } \mu g^{\prime} g \text { ) }\end{array}$ & $\begin{array}{c}\text { Sto.. Dev. } \\
\left(\mu g^{\prime} g\right)\end{array}$ & $\begin{array}{c}\text { HTF }-002 \\
\text { Tk 43H } \\
\text { VDS } \\
\text { Average } \\
(\mu g / g)\end{array}$ & $\begin{array}{c}\text { Stu. Dev. } \\
(\mu g / g)\end{array}$ & $\begin{array}{c}\text { ITP-309 } \\
\text { Tk 41H } \\
\text { Salt } \\
\text { Average } \\
(\mu \mathrm{g} / \mathrm{g})\end{array}$ & $\begin{array}{l}\text { Sid. Dev } \\
(\mu g / g)\end{array}$ \\
\hline Total U & 15 & 2.8 & 3.9 & 0.11 & 120 & 1.9 & 39 & 14 \\
\hline U.233 & bdl & - & boll & - & bdl & - & 0.056 & 0.012 \\
\hline$U .234$ & 1.7 & 0.28 & 0.30 & 0.028 & 6.5 & 0.30 & 0.68 & 0.077 \\
\hline$U-235$ & 0.57 & 0.14 & 0.11 & 0.0046 & 3.2 & 0.21 & 1.7 & 0.26 \\
\hline U.236 & 0.21 & 0.027 & 0.050 & 0.016 & 1.2 & 0.065 & 0.83 & 0.12 \\
\hline$U \cdot 238$ & 12 & 2.4 & 3.4 & 0.084 & 110 & 1.4 & 36 & 13 \\
\hline Total $\mathrm{Pu}$ & 0.38 & 0.075 & 0.85 & 0.11 & 9.7 & 0.84 & 11 & 4.3 \\
\hline $\mathrm{Pu-239}$ & 0.38 & 0.075 & 0.78 & 0.093 & 7.0 & 0.82 & 10 & 4.3 \\
\hline$P u-240$ & bdl & - & 0.059 & 0.021 & 1.1 & 0.066 & 0.13 & 0.040 \\
\hline$P u-241$ & bdl & - & 0.0080 & 0.0032 & 1.4 & 0.087 & 0.018 & 0.0063 \\
\hline $\mathrm{Pu-242}$ & bdl & - & 0.0041 & 0.0035 & 0.25 & 0.082 & 0.014 & 0.0095 \\
\hline Eq. U & 2.1 & 0.44 & 3.2 & 0.36 & 36 & 3.4 & 44 & 17 \\
\hline $\mathbf{N a}$ & 350000 & 55000 & 300000 & 9100 & 330000 & 12000 & 400000 & 16000 \\
\hline $\mathrm{Fe}$ & 230 & 29 & 260 & 100 & 19000 & 640 & 6000 & 5300 \\
\hline $\mathrm{Cr}$ & 400 & 66 & 120 & 23 & 5500 & 210 & 2500 & 82 \\
\hline$Z_{\mathbf{n}}$ & 22 & 12 & 19 & 4.5 & 160 & 13 & 26 & 14 \\
\hline $\mathbf{M n}$ & 94 & 16 & 370 & 44 & 15000 & 590 & 240 & 320 \\
\hline
\end{tabular}

\section{Weight \% Solids}

\begin{tabular}{|c|c|c|c|c|c|c|c|}
\hline \multirow[t]{2}{*}{$\begin{array}{c}\text { Average } \\
65.9\end{array}$} & $\begin{array}{c}\text { Std. Dev. } \\
0.53\end{array}$ & $\begin{array}{c}\text { Average } \\
-\end{array}$ & Std. Dev. & $\begin{array}{c}\text { Average } \\
50.9\end{array}$ & $\begin{array}{c}\text { Std. Dev. } \\
1.85\end{array}$ & $\begin{array}{c}\text { Average } \\
-\end{array}$ & Std. Dev. \\
\hline & \multicolumn{7}{|c|}{ Weight Ratio } \\
\hline $\begin{array}{l}\text { Average } \\
170000\end{array}$ & $\begin{array}{c}\text { Std. Dev. } \\
11000\end{array}$ & $\begin{array}{l}\text { Average } \\
97000\end{array}$ & $\begin{array}{c}\text { Std. Dev. } \\
14000\end{array}$ & $\begin{array}{c}\text { Average } \\
9100\end{array}$ & $\begin{array}{c}\text { Std. Dev. } \\
940\end{array}$ & $\begin{array}{c}\text { Average } \\
10000\end{array}$ & $\begin{array}{c}\text { Std. Dev. } \\
3100\end{array}$ \\
\hline 110 & 14 & 83 & 28 & 520 & 52 & 170 & 180 \\
\hline 190 & 17 & 39 & 8.3 & 220 & 16 & 63 & 20 \\
\hline 14 & 4.8 & 6.1 & 0.92 & 4.6 & 0.69 & 0.70 & 0.53 \\
\hline 45 & 3.2 & 120 & 22 & 420 & 44 & 7.2 & 10 \\
\hline
\end{tabular}

Actinide results are those determined by ICP-MS and corrected based on the U-238 result with the glass standard. Mass 238 is reported as U-238 and is not corrected for any Pu-238 present. Mass 241 is reported as Pu-241 and not corrected for Am-241 present. Total Pu is calculated as the sum of Pu-239, Pu-240, Pu241 and Pu-242. Equivalent uranium fissile content (Eq. $U$ ) is calculated as the sum of U-233, U-235 and four times the sum of Pu-239 and Pu-241 [ref. 9]. Sodium, iron, chromium, zinc and manganese results are those determined by ICP-ES and corrected for acid blanks and glass standard responses. Weight percent solids (wt \%) were determined by weighing samples before and after drying at $100^{\circ} \mathrm{C}$ prior to dissolution in aqua regia. Weight ratios were determined by dividing measured metal concentration by the equivalent uranium fissile concentration.

bdl $=$ below detection limit 
Table II. Analytical Results for the Solids Fraction in the Tank $38 \mathrm{H}$ and Tank 43H VDS Samples.

\begin{tabular}{|c|c|c|c|c|c|c|}
\hline \multirow{3}{*}{$\begin{array}{c}\text { Total U } \\
U-233\end{array}$} & \multicolumn{2}{|c|}{\begin{tabular}{|cc} 
HTF.001 & \\
Tk 38H VDS & \\
Average & Std. Dev. \\
$(\mu \mathrm{g} / \mathrm{g})$ & $(\mu \mathrm{g} / \mathrm{g})$ \\
\end{tabular}} & $\begin{array}{r}\text { HTF.00 } \\
\text { Tk 38H } \\
\text { Average } \\
(\mu \mathrm{g} / \mathrm{g}) \\
\end{array}$ & $\begin{array}{c}\text { Std. Dev. } \\
(\mu g / g)\end{array}$ & $\begin{array}{r}\text { HTF }-0 \\
\text { Tk } 43 H \\
\text { Average } \\
(\mu g / g) \\
\end{array}$ & $\begin{array}{c}\text { Std. Dev. } \\
(\mu g / g)\end{array}$ \\
\hline & 22 & 1.2 & 20 & 0.31 & 140 & 2.9 \\
\hline & bdl & - & 0.011 & 0.019 & 0.080 & 0.010 \\
\hline$U \cdot 234$ & 1.0 & 0.096 & 1.5 & 0.040 & 8.3 & 0.15 \\
\hline U.235 & 0.365 & 0.037 & 0.54 & 0.016 & 3.9 & 0.12 \\
\hline U-236 & 0.16 & 0.028 & 0.20 & 0.027 & 1.5 & 0.052 \\
\hline $\mathrm{U}-238$ & 21 & 1.2 & 18 & 0.24 & 120 & 2.6 \\
\hline Total Pu & 1.1 & 0.090 & 0.83 & 0.033 & 8.3 & 0.36 \\
\hline Pu-239 & 0.86 & 0.069 & 0.70 & 0.016 & 6.5 & 0.24 \\
\hline$P u-240$ & 0.14 & 0.024 & 0.092 & 0.012 & 0.88 & 0.057 \\
\hline $\mathrm{Pu}-241$ & 0.054 & 0.0088 & 0.036 & 0.0062 & 0.78 & 0.084 \\
\hline $\mathrm{Pu}-242$ & 0.021 & 0.018 & bdl & - & 0.18 & 0.012 \\
\hline Eq. U & 4.0 & 0.34 & 3.5 & 0.10 & 33 & 1.3 \\
\hline $\mathrm{Na}$ & 360000 & 26000 & 260000 & 4900 & 220000 & 1200 \\
\hline $\mathrm{Fe}$ & 900 & 92 & 470 & 9.5 & 22000 & 160 \\
\hline Cr & 700 & 53 & 410 & 5.1 & 5900 & 36 \\
\hline $\mathbf{Z n}$ & $<37$ & 7.5 & 6.4 & 2.1 & 170 & 0.76 \\
\hline $\mathbf{M n}$ & 2400 & 170 & 170 & 5.1 & 17000 & 85 \\
\hline
\end{tabular}

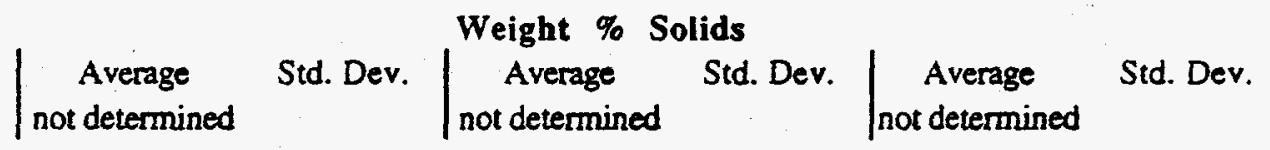

\begin{tabular}{l|cc|cc|cc} 
& \multicolumn{7}{|c|}{ Weight Ratio } \\
Na/Eq. U & Average & Std. Dev. & Average & Std. Dev. & Average & Std. Dev. \\
Fe/Eq. U & 90000 & 1600 & 75000 & 790 & 6500 & 230 \\
Cr/Eq. U & 220 & 4.3 & 130 & 2.1 & 660 & 22 \\
Zn/Eq. U & 290 & 2.1 & 120 & 3.2 & 180 & 6.2 \\
Mn/Eq. U & 610 & 2.0 & 1.8 & 0.56 & 5.3 & 0.19 \\
& 10 & 49 & 0.79 & 520 & 19
\end{tabular}

Solid-liquid separation for sample HTF-001 performed in 772-F by filtration. Solids shipped to SRTC for analysis. Solid-liquid separation for samples HTF-004 and HTF-002 performed in 773-A by centrifugation and decantation. Actinide results are those determined by ICP-MS and corrected based on the U-238 result with the glass standard. Mass 238 is reported as U-238 and is not corrected for any Pu-238 present. Mass 241 is reported as Pu-241 and not corrected for Am-241 present. Total Pu is calculated as the sum of Pu239, Pu-240, Pu-241 and Pu-242. Equivalent uranium fissile content (Eq. $U$ ) is calculated as the sum of $U$ 233. U-235 and four times the sum of Pu-239 and Pu-241 [ref. 9]. Sodium, iron, chromium. zinc and manganese results are those determined by ICP.ES and corrected for acid blanks and glass standard responses. Weight ratios were determined by dividing measured metal concentration by the equivalent uranium fissile concentration. $\quad$ bdl = below detection limit 
Table III. Analytical Results for the Water Insoluble Solids in the Tank $38 H$ and Tank $41 H$ Salt Samples.

\begin{tabular}{|c|c|c|c|c|}
\hline & $\begin{array}{c}\text { HTF-003 } \\
\text { Tk 38H Sait } \\
\text { Average } \\
(\mu g / g) \\
\end{array}$ & $\begin{array}{c}\text { Std. Dev. } \\
(\mu g / g)\end{array}$ & $\begin{array}{c}\text { ITP.309 } \\
\text { Tank } 41 \mathrm{H} \text { Salt } \\
\text { Average } \\
(\mu \mathrm{g} / \mathrm{g}) \\
\end{array}$ & $\begin{array}{c}\text { Std. Dev. } \\
(\mu \mathrm{g} / \mathrm{g})\end{array}$ \\
\hline Total U & 180 & 3.5 & 240 & 78 \\
\hline$U \cdot 233$ & 0.056 & 0.080 & 0.98 & 0.44 \\
\hline$U \cdot 234$ & 8.3 & 0.080 & 9.0 & 3.0 \\
\hline$U-235$ & 3.1 & 0.080 & 23 & 7.6 \\
\hline$U .236$ & 1.2 & 0.00 & 9.9 & 3.4 \\
\hline$U-238$ & 170 & 3.3 & 190 & 63 \\
\hline Total Pu & 12 & 0.23 & 1.5 & 0.72 \\
\hline $\mathrm{Pu} \cdot 239$ & 10 & 0.28 & 1.2 & 0.57 \\
\hline $\mathrm{Pu} \cdot \mathbf{2 4 0}$ & 1.4 & 0.057 & 0.18 & 0.077 \\
\hline$P u-241$ & 0.48 & 0.00 & 0.090 & 0.077 \\
\hline $\mathrm{Pu}-242$ & 0.24 & 0.00 & bdl & - \\
\hline Eq. U & 45 & 1.2 & 30 & 11 \\
\hline $\mathrm{Na}$ & 170000 & 5200 & 100000 & 28000 \\
\hline $\mathrm{Fe}$ & 29000 & 940 & 30000 & 12000 \\
\hline $\mathrm{Cr}$ & 14000 & 420 & 8200 & 6700 \\
\hline $\mathbf{Z n}$ & 210 & 32 & 140 & 26 \\
\hline $\mathbf{M n}$ & 56000 & 1800 & 570 & 300 \\
\hline \multicolumn{5}{|c|}{ Weight \% Solids } \\
\hline & Average & Std. Dev. & Average & Std. Dev. \\
\hline & 0.492 & 0.0035 & 1.39 & 0.283 \\
\hline \multicolumn{5}{|c|}{ Weight Ratio } \\
\hline & Average & Std. Dev. & Average & Std. Dev. \\
\hline a/Eq. U & 2900 & 11 & 3600 & 340 \\
\hline $\mathrm{Fe} / \mathrm{Eq} \cdot \mathrm{U}$ & 430 & 2.2 & 1000 & 61 \\
\hline $\mathrm{Cr} / \mathbf{E q} \cdot \mathrm{U}$ & 220 & 0.53 & 250 & 140 \\
\hline $\mathbf{Z n} / \mathbf{E q} \cdot \mathbf{U}$ & 43.3 & 0.41 & 5.0 & 1.0 \\
\hline $\mathbf{M n} / \mathbf{E q} \cdot \mathbf{U}$ & 870 & 4.7 & 19 & 3.5 \\
\hline
\end{tabular}

Actinide results are those determined by ICP-MS and corrected based on the U-238 result with the glass standard. Mass 238 is reported as U-238 and is not corrected for any Pu-238 present. Mass 241 is reported as Pu-241 and not corrected for Am-241 present. Total Pu is calculated as the sum of Pu-239, Pu-240, Pu241 and Pu-242. Equivalent uranium fissile content (Eq. $U$ ) is calculated as the sum of U-233, U-235 and four times the sum of Pu-239 and Pu-241 [ref. 9]. Sodjum, iron, chromium, zinc and manganese results are those determined by ICP-ES and corrected for acid blanks and glass standard responses. Weight percent insolubles is the weight percent of the dried solids after removal of water soluble material from the damp asreceived salt. Weight ratios were determined by dividing measured metal concentration by the equivalent uranium fissile concentration. $\quad$ bdl $=$ below detection limit 
Table IV. Analytical Results for the Water Insoluble Solids in the Tank 38H and Tank 43H VDS Samples.

\begin{tabular}{c|cc|cc} 
& $\begin{array}{c}\text { HTF-004 } \\
\text { Tk 38H VDS } \\
\text { Average } \\
(\mu \mathrm{g} / \mathrm{g})\end{array}$ & $\begin{array}{c}\text { Std. Dev. } \\
(\mu \mathrm{g} / \mathrm{g})\end{array}$ & $\begin{array}{c}\text { HTF-002 } \\
\text { Tank 43H VDS } \\
\text { Average } \\
(\mu \mathrm{g} / \mathrm{g})\end{array}$ & $\begin{array}{c}\text { Std. Dev. } \\
(\mu \mathrm{g} / \mathrm{g})\end{array}$ \\
\cline { 2 - 5 } Total U & 38 & 0.86 & 410 & 12 \\
U-233 & bdl & - & 0.27 & 0.039 \\
U-234 & 1.4 & 0.15 & 20 & 0.16 \\
U-235 & 0.56 & 0.019 & 10 & 0.44 \\
U-236 & 0.24 & 0.037 & 3.8 & 0.1 \\
U-238 & 35 & 0.85 & 380 & 12 \\
& & & & \\
Total Pu & 16 & 0.64 & 140 & 3.5 \\
Pu-238 & 11 & 0.52 & 91 & 3.7 \\
Pu-239 & 3.8 & 0.17 & 28 & 0.22 \\
Pu-240 & 0.64 & 0.044 & 4.5 & 0.055 \\
Pu-241 & 0.19 & 0.065 & 0.00 & 0.00 \\
Pu-242 & 0.16 & 0.066 & 1.1 & 0.042 \\
A m-241 & 0.15 & 0.011 & 6.5 & 0.022 \\
& & & & \\
Equiv. U & 17 & 0.80 & 170 & 1.3 \\
& & & & \\
Na & 270000 & 3900 & 200000 & 280 \\
Fe & 1600 & 20 & 70000 & 380 \\
Cr & 670 & 9.1 & 9500 & 10 \\
Zn & 110 & 2.4 & 680 & 2.6 \\
Mn & 570 & 8.6 & $<1.7$ & 0.00 \\
& & & &
\end{tabular}

\begin{tabular}{cc|cc}
\multicolumn{4}{c}{ Weight \% } \\
Average & Std. Dev. & Average & Std. Dev. \\
9.81 & - & 16.3 & -
\end{tabular}

\begin{tabular}{c|cc|cc} 
& \multicolumn{4}{|c}{ Weight Ratio } \\
Na/Eq. U & Average & Std. Dev. & Average & Std. Dev. \\
Fe/Eq. U & 16000 & 1000 & 1200 & 10 \\
Cr/Eq. U & 98 & 5.4 & 420 & 4.8 \\
Zn/Eq. U & 40 & 2.3 & 56 & 0.49 \\
Mn/Eq. U & 6.7 & 0.45 & 4.1 & 0.036 \\
& 34 & 2.0 & $<0.010$ & 0.000079
\end{tabular}

Actinide results are those determined by ICP-MS and corrected based on the U-238 result with the giass standard. U-238 is difference between mass-238 determined by ICP-MS and PU-238 determined by alpha spectroscopy. Pu241 is difference between mass-241 determined by ICP-MS and Am-241 determined by gamma spectroscopy. Total Pu is calculated as the sum of Pu-238, Pu-239, Pu-240, Pu-241 and Pu-242. Equivalent uranium fissile content (Eq. $U$ ) is calculated as the sum of U-233, U-235 and four times the sum of Pu-239 and Pu-241 [ref. 9 ]. Sodium, iron, chromium, zinc and manganese-results are those determined by ICP.ES and corrected for acid blanks and glass standard responses. Weight percent insolubles is the weight percent of the dried solids after removal of liquid and water soluble material from the as-received sample ( 100 times grams dried insoluble solids divided by grams as-received slurry sample). Weight ratios were determined by dividing measured metal concentration by the equivalent uranium fissile concentration. 
Appendices $\mathbf{1 . 5}$

\author{
Complete Analytical Results and Calculated Weight Ratios for \\ Tank 38H VDS Sample HTF-001 \\ Tank 43H VDS Sample HTF-002 \\ Tank 38H Saltcake Sample HTF-003 \\ Tank 38H VDS Sample HTF-004 \\ Tank 41H Saltcake Sample $41 S C 0696$
}

The following notes apply to all results reported in the Appendices. Actinide results are those determined by ICP-MS and corrected based on the U-238 result with the glass standard. Unless a Pu-238 result is reported, mass 238 is reported as U-238. Unless an Am-241 result is reported, mass 241 is reported as Pu-241. Total Pu is calculated as the sum of $\mathrm{Pu}-239, \mathrm{Pu}-240, \mathrm{Pu}-241$ and $\mathrm{Pu}-242$. In selected samples, $\mathrm{Pu}-238$ determined by alpha spectroscopy and Am-241 determined by gamma spectroscopy. For these samples, the U-238 is equal to the mass 238 minus the Pu-238. Pu-241 is mass 241 minus Am241. Total Pu for these samples calculated as the sum of Pu-238, Pu-239, Pu-240, Pu-241 and $\mathrm{Pu}-242$. Equivalent uranium fissile content (Eq. $U$ ) is calculated as the sum of U-233, U-235 and four times the sum of Pu-239 and Pu-241 [ref. 9]. Sodium, iron, chromium, zinc, manganese, boron, lithium, calcium, magnesium, nickel and titanium results are those determined by ICP-ES and corrected for acid blanks and glass standard responses. All other elements determined by ICP-ES are corrected for acid blanks only. Weight percent solids (wt \%) were determined by weighing samples before and after drying at $100^{\circ} \mathrm{C}$ prior to dissolution in aqua regia. Weight ratios were determined by dividing measured metal concentration by the equivalent uranium fissile concentration.

$$
\mathrm{bdl}=\text { below detection limit } \quad \text { nd }=\text { not determined }
$$




\section{Appendix 1.}

Complete ICP.ES and ICP-MS Results and Calculated Weight Ratios for Tank 38H VDS Sample HTF-001

\begin{tabular}{|c|c|c|c|c|c|c|}
\hline Element & & $\begin{array}{l}\text { Average } \\
(\mu g / g)\end{array}$ & $\begin{array}{l}\text { Std. Dev. } \\
(\mu g / g)\end{array}$ & $\begin{array}{l}\text { Solids Fractio } \\
\text { Weight Ratio }\end{array}$ & Average & Std. Dev. \\
\hline Al & & $9.8 E+03$ & $6.5 \mathrm{E}+02$ & Al/Eq. U & $2.4 E+03$ & $4.5 E+01$ \\
\hline B & & $7.5 E+01$ & $2.6 \mathrm{E}+01$ & B/Eq. U & $1.8 E+01$ & $5.0 \mathrm{E}+00$ \\
\hline $\mathrm{Ba}$ & $<$ & $8.1 E+00$ & $6.8 \mathrm{E}-02$ & $\mathrm{Ba} / \mathbf{E q} \cdot \mathrm{U}$ & $<2.0 \mathrm{E}+00$ & $1.9 \mathrm{E}-01$ \\
\hline $\mathrm{Ca}$ & & $3.7 \mathrm{E}+02$ & $2.8 E+01$ & $\mathrm{Ca} / \mathrm{Eq} \cdot \mathrm{U}$ & $9.1 \mathrm{E}+01$ & $1.2 E+00$ \\
\hline $\mathrm{Cd}$ & $<$ & $4.0 E+00$ & $3.3 \mathrm{E}-02$ & $\mathrm{Cd} / \mathrm{Eq} . \mathrm{U}$ & $<1.0 \mathrm{E}+00$ & $9.5 \mathrm{E}-02$ \\
\hline Co & $<$ & $1.7 \mathrm{E}+01$ & $1.4 \mathrm{E}-01$ & $\mathrm{Co} / \mathrm{Eq} \cdot \mathrm{U}$ & $<4.2 E+00$ & 4.0E-01 \\
\hline $\mathrm{Cr}$ & & $7.0 \mathrm{E}+02$ & $5.3 E+01$ & $\mathrm{Cr} / \mathrm{Eq} . \mathrm{U}$ & $1.8 \mathrm{E}+02$ & $2.1 E+00$ \\
\hline $\mathrm{Cu}$ & $<$ & $1.8 \mathrm{E}+01$ & $1.5 \mathrm{E}-01$ & $\mathrm{Cu} / \mathrm{Eq} . \mathrm{U}$ & $<4.6 E+00$ & $4.3 E-01$ \\
\hline $\mathrm{Fe}$ & & $9.0 \mathrm{E}+02$ & $9.2 E+01$ & $\mathrm{Fe} / \mathrm{Eq} . \mathrm{U}$ & $2.2 E+02$ & $4.3 E+00$ \\
\hline $\mathrm{La}$ & $<$ & $5.7 \mathrm{E}+01$ & $4.8 \mathrm{E}-01$ & $\mathrm{La} / \mathrm{Eq} . \mathrm{U}$ & $<1.4 \mathrm{E}+01$ & $1.4 \mathrm{E}+00$ \\
\hline $\mathrm{Li}$ & $<$ & $1.9 \mathrm{E}+01$ & $1.6 \mathrm{E}-01$ & Li/Eq. U & $<4.8 E+00$ & 4.5E-01 \\
\hline $\overrightarrow{M g}$ & & $3.1 E+01$ & $1.8 E+\infty 0$ & $\mathrm{Mg} / \mathrm{Eq} \cdot \mathrm{U}$ & $7.8 E+\infty$ & 2.3E-01 \\
\hline Mn & & $2.4 E+03$ & $1.7 E+02$ & Mn/Eq. U & $6.1 E+02$ & $1.0 \mathrm{E}+01$ \\
\hline Mo & $<$ & $6.7 E+00$ & $5.6 \mathrm{E}-02$ & $\mathrm{Mo} / \mathbf{E q} \cdot \mathrm{U}$ & $<1.7 E+00$ & $1.6 \mathrm{E}-01$ \\
\hline $\mathrm{Na}$ & & $3.6 E+05$ & $2.6 E+04$ & $\mathrm{Na} / \mathbf{E q} \cdot \mathrm{U}$ & $9.0 \mathrm{E}+04$ & $1.6 E+03$ \\
\hline $\mathbf{N i}$ & & $2.3 E+01$ & $2.7 \mathrm{E}+00$ & Ni/Eq. U & $5.9 E+\infty 0$ & $1.2 E+00$ \\
\hline$P$ & & $2.1 \mathrm{E}+03$ & $1.5 \mathrm{E}+02$ & P/Eq. U & $5.3 E+02$ & $9.4 E+00$ \\
\hline $\mathbf{P b}$ & $<$ & $1.1 E+02$ & $9.1 E-01$ & $\mathrm{~Pb} / \mathrm{Eq} . \mathrm{U}$ & $<2.8 \mathrm{E}+01$ & $2.6 E+\infty 0$ \\
\hline Sn & $<$ & $1.9 \mathrm{E}+01$ & $1.6 \mathrm{E}-01$ & Sn/Eq. U & $<4.9 \mathrm{E}+00$ & $4.6 \mathrm{E}-01$ \\
\hline $\mathbf{S r}$ & $<$ & $3.3 E+00$ & $2.8 \mathrm{E}-02$ & Sr/Eq. U & $<8.4 \mathrm{E}-01$ & 8.0E-02 \\
\hline $\mathbf{T i}$ & $<$ & $1.4 E+01$ & $1.2 \mathrm{E}-01$ & Ti/Eq. U & $<3.5 \mathrm{E}+00$ & $3.3 \mathrm{E}-01$ \\
\hline $\mathbf{v}$ & $<$ & $1.4 \mathrm{E}+01$ & $1.2 \mathrm{E}-01$ & V/Eq. U & $<3.5 E+\infty$ & $3.3 \mathrm{E}-01$ \\
\hline$Z_{n}$ & $<$ & $3.7 \mathrm{E}+01$ & $7.5 E+00$ & $\mathrm{Zn} / \mathbf{E q} . \mathrm{U}$ & $<9.3 E+00$ & $2.0 E+00$ \\
\hline $\mathbf{Z r}$ & $<$ & $1.8 \mathrm{E}+01$ & $1.5 \mathrm{E}-01$ & $\mathrm{Zr} / \mathbf{E q} \cdot \mathbf{U}$ & $<4.5 \mathrm{E}+\infty 0$ & 4.3E-01 \\
\hline Isotope & & $(\mu g / g)$ & $(\mu g / g)$ & & & \\
\hline$U .233$ & & $0.0 \mathrm{E}+00$ & $0.0 \mathrm{E}+00$ & & & \\
\hline U-234 & & $1.0 \mathrm{E}+\infty 0$ & $9.6 \mathrm{E}-02$ & & & \\
\hline$U-235$ & & $3.6 \mathrm{E}-01$ & $3.7 \mathrm{E}-02$ & & & \\
\hline$U-236$ & & $1.6 \mathrm{E}-01$ & $2.8 \mathrm{E}-02$ & & & \\
\hline$N p-237$ & & $4.8 \mathrm{E}-01$ & $4.0 \mathrm{E}-02$ & & & \\
\hline $\mathrm{U}-238$ & & $2.1 E+01$ & $1.2 \mathrm{E}+00$ & & & \\
\hline Pu-238 & & nd & - & & & \\
\hline Pu-239 & & $8.6 E-01$ & $6.9 \mathrm{E}-02$ & & & \\
\hline$P u-240$ & & $1.4 \mathrm{E}-01$ & $2.4 E-02$ & & & \\
\hline$P u-241$ & & $5.3 E-02$ & 8.8E-03 & & & \\
\hline $\mathrm{Pu}^{\mathrm{P}}$ & & $2.1 E-02$ & $1.9 \mathrm{E}-02$ & & & \\
\hline Total $\mathbf{U}$ & & $2.2 \mathrm{E}+01$ & $1.2 E+00$ & & & \\
\hline$\% \quad \mathrm{U} \cdot 235$ & & $1.6 E+00$ & $1.2 E-01$ & & & \\
\hline$\% \quad U .238$ & & $9.3 E+01$ & $4.6 \mathrm{E}-01$ & & & \\
\hline Total $\mathbf{P u}$ & & $1.1 \mathrm{E}+00$ & $9.0 \mathrm{E}-02$ & & & \\
\hline Equiv. Fissile & $\mathbf{U}$ & $4.0 \mathrm{E}+\infty 0$ & $3.4 \mathrm{E}-01$ & & & \\
\hline
\end{tabular}


Appendix 2A. Complete ICP-ES and ICP-MS Results for Tank 38H VDS Sample
HTF-002

\begin{tabular}{|c|c|c|c|c|c|c|c|c|}
\hline Element & \multicolumn{2}{|c|}{$\begin{array}{l}\text { Total Sample } \\
\text { Average Std. Dev. } \\
\text { ( } \mu \text { g/g dried sample) }\end{array}$} & \multicolumn{2}{|c|}{$\begin{array}{l}\text { Liquid Fraction } \\
\text { Average Sti. Dev. } \\
\text { ( } \mu \text { g/g liquid) }\end{array}$} & \multicolumn{2}{|c|}{$\begin{array}{l}\text { Solids Fraction } \\
\text { Average Std. Dev. } \\
\text { (ug/g dried solids) }\end{array}$} & \multicolumn{2}{|c|}{$\begin{array}{l}\text { Insoluble Solids } \\
\text { Average Sid. Dev. } \\
\text { ( } \mu \mathrm{g} / \mathrm{g} \text { insol. solids) }\end{array}$} \\
\hline AI & $2.1 E+04$ & $7.8 E+02$ & $9.9 E+03$ & $1.6 \mathrm{E}+03$ & $1.2 E+04$ & $9.2 E+01$ & $3.6 E+04$ & $9.6 E+01$ \\
\hline B & $1.9 E+02$ & $1.8 E+01$ & $6.6 E+01$ & 2.6́E+01 & $6.7 E+02$ & $6.4 E+00$ & $7.8 E+02$ & $5.0 \mathrm{E}+00$ \\
\hline $\mathbf{B a}$ & $2.4 \mathrm{E}+03$ & $4.1 E+03$ & $<5.2 \mathrm{E}+00$ & 7.1E-01 & $9.3 E+01$ & $1.4 \mathrm{E}+\infty$ & $3.2 \mathrm{E}+02$ & $2.1 E+00$ \\
\hline $\mathbf{C a}$ & $1.3 E+04$ & $5.0 \mathrm{E}+02$ & $3.2 E+\infty$ & $3.6 \mathrm{E}+00$ & $1.7 E+04$ & $8.7 E+01$ & $\mid<1.0 E+00$ & $0.0 \mathrm{E}+00$ \\
\hline Cd & 2.1E+01 & $1.9 E+00$ & $<2.5 E+\infty$ & $3.6 \mathrm{E}-01$ & $2.0 E+01$ & $1.7 E+\infty$ & $7.2 E+01$ & $1.1 E+\infty$ \\
\hline $\mathrm{Co}$ & $2.2 E+01$ & $3.3 E+\infty 0$ & $<1.1 E+01$ & $1.5 E+00$ & $<7.8 E+00$ & $0.0 E+00$ & 3.7E+01 & $2.0 E+00$ \\
\hline $\mathrm{Cr}$ & $5.5 E+03$ & 2.1E+02 & $5.8 E+02$ & 8.7E+01 & $5.9 \mathrm{E}+03$ & $3.6 \mathrm{E}+01$ & $9.5 E+03$ & $1.0 \mathrm{E}+01$ \\
\hline $\mathrm{Cu}$ & $7.3 E+01$ & $6.7 E+00$ & $<1.2 \mathrm{E}+01$ & $1.7 E+\infty 0$ & $4.7 E+01$ & $1.9 \mathrm{E}+00$ & $1.9 E+02$ & $3.9 E+00$ \\
\hline $\mathrm{Fe}$ & $1.9 E+04$ & $6.4 E+02$ & $1.6 \mathrm{E}+01$ & $4.4 E+00$ & $2.2 \bar{E}+04$ & $1.6 E+02$ & $7.0 E+04$ & $3.8 E+02$ \\
\hline La & $<2.0 E+01$ & $1.2 E+00$ & $<3.7 E+01$ & $5.2 E+\infty 0$ & $\mid<2.7 E+01$ & $0.0 \mathrm{E}+00$ & $<3.4 E+01$ & $0.0 \mathrm{E}+00$ \\
\hline $\mathbf{L i}$ & $7.8 \mathrm{E}+01$ & $7.4 \mathrm{E}+00$ & $<1.1 E+01$ & $1.7 \mathrm{E}+00$ & $6.7 \mathrm{E}+01$ & 8.1E-01 & $2.7 E+02$ & $2.4 \mathrm{E}+00$ \\
\hline $\mathbf{M g}$ & $1.0 E+03$ & $4.0 E+01$ & $9.8 \mathrm{E}-01$ & 9.1E-03 & $1.2 E+03$ & $6.9 E+\infty$ & $3.8 E+03$ & $1.3 E+01$ \\
\hline Mn & $1.5 \mathrm{E}+04$ & $5.9 E+02$ & $2.0 E+01$ & $1.5 E+01$ & $1.7 E+04$ & $8.5 E+01$ & $<1.7 \mathrm{E}+00$ & $0.0 \mathrm{E}+00$ \\
\hline Mo & $6.4 \mathrm{E}+01$ & $4.1 E+00$ & $2.1 E+01$ & $1.2 E+\infty 0$ & $2.7 \mathrm{E}+0 \mathrm{l}$ & $1.2 E+\infty$ & $2.2 \mathrm{E}+01$ & 2.1E+00 \\
\hline $\mathrm{Na}$ & $3.3 E+05$ & $1.2 \mathrm{E}+04$ & $1.8 E+05$ & $3.0 \mathrm{E}+04$ & $2.2 \mathrm{E}+05$ & $1.2 \mathrm{E}+03$ & $2.0 \mathrm{E}+05$ & $2.8 \mathrm{E}+02$ \\
\hline $\mathrm{Ni}$ & $1.6 E+03$ & $6.0 \mathrm{E}+01$ & $<1.3 E+01$ & $1.9 E+00$ & $1.8 \mathrm{E}+03$ & $1.7 \mathrm{E}+01$ & $6.0 E+03$ & $2.1 E+01$ \\
\hline $\mathbf{P}$ & $4.1 E+03$ & $1.8 E+02$ & $5.3 E+02$ & 4.7E+01 & $3.9 E+03$ & $9.0 \mathrm{E}+01$ & $1.3 E+04$ & $2.9 \mathrm{E}+01$ \\
\hline $\mathbf{P} \mathbf{b}$ & $1.6 E+02$ & $1.3 E+01$ & $<7.0 \mathrm{E}+01$ & $9.8 E+\infty 0$ & $8.8 E+01$ & $2.0 \mathrm{E}+01$ & $3.1 E+02$ & $1.9 E+01$ \\
\hline Sn & $2.2 E+01$ & $1.4 \mathrm{E}+00$ & $<1.2 E+01$ & $1.7 E+\infty 0$ & $9.2 E+00$ & $3.4 \mathrm{E}-01$ & $2.8 E+03$ & $1.1 E+03$ \\
\hline Sr & $4.9 E+01$ & $2.3 E+00$ & $<2.1 E+00$ & 2.7E-01 & $5.3 E+01$ & $5.6 \mathrm{E}-01$ & $1.6 E+02$ & $9.4 E-01$ \\
\hline $\mathbf{T} \mathbf{i}$ & $6.9 E+01$ & $8.1 E+00$ & $<8.1 \mathrm{E}+00$ & $1.2 E+\infty$ & $5.5 \mathrm{E}+01$ & $1.6 \mathrm{E}+00$ & $3.8 E+02$ & $7.6 \mathrm{E}+01$ \\
\hline $\mathbf{V}$ & $2.3 E+01$ & $4.6 E+\infty 0$ & $<8.9 E+\infty$ & $1.3 E+\infty 0$ & $<6.5 E+00$ & $8.4 E-08$ & $<8.4 E+00$ & $0.0 E+\infty 0$ \\
\hline $\mathbf{Z}_{\mathbf{n}}$ & $1.6 E+02$ & $1.3 E+01$ & $4.6 \mathrm{E}+01$ & $6.5 E+00$ & 1.7E+02 & $7.6 \mathrm{E}-01$ & $6.8 \mathrm{E}+02$ & $2.6 E+00$ \\
\hline $\mathbf{Z r}$ & $1.8 E+01$ & $6.0 \mathrm{E}+00$ & $<1.1 E+01$ & $1.6 E+00$ & $\mid<8.4 E+00$ & $0.0 E+00$ & $<1.1 E+01$ & $0.0 \mathrm{E}+00$ \\
\hline \multicolumn{9}{|l|}{ Isotope } \\
\hline $\mathrm{U}-233$ & $0.0 \mathrm{E}+00$ & $0.0 \mathrm{E}+00$ & $7.4 \mathrm{E}-03$ & $1.3 \mathrm{E}-02$ & $8.0 \mathrm{E}-02$ & $1.0 \mathrm{E}-02$ & $2.7 \mathrm{E}-01$ & $3.9 \mathrm{E}-02$ \\
\hline$U-234$ & $6.5 E+00$ & 3.0E-01 & 5.5E-01 & $1.0 \mathrm{E}-01$ & $8.3 E+00$ & $1.5 \mathrm{E}-01$ & +01 & -01 \\
\hline U.235 & $3.2 E+00$ & $2.1 E-01$ & $4.4 \mathrm{E}-01$ & $7.0 \mathrm{E}-02$ & $3.9 E+\infty 0$ & $1.2 E-01$ & $1.0 E+01$ & $4.4 \mathrm{E}-01$ \\
\hline $\mathrm{U} \cdot \mathbf{2 3 6}$ & $1.2 \mathrm{E}+00$ & $6.7 \mathrm{E}-02$ & $1.8 \mathrm{E}-01$ & $3.2 \mathrm{E}-02$ & $1.5 E+\infty$ & 5.1E-02 & $3.8 E+00$ & $1.0 \mathrm{E}-01$ \\
\hline$N p-237$ & $1.3 E+01$ & 2.1E-01 & 2.7E-01 & $3.6 \mathrm{E}-02$ & $1.6 \mathrm{E}+01$ & $5.7 \mathrm{E}-01$ & $4.9 E+01$ & 1.1E-01 \\
\hline U.238 & $1.1 E+02$ & $1.4 E+00$ & $3.8 E+\infty 0$ & $6.1 E-01$ & $1.2 \mathrm{E}+02$ & $2.6 E+\infty 0$ & $3.8 E+02$ & $1.2 E+01$ \\
\hline$P u-238$ & nd & - & nd & - & nd & - & $9.1 E+01$ & $3.7 E+\infty 0$ \\
\hline Pu-239 & $7.0 \mathrm{E}+00$ & $8.2 E-01$ & $0.0 E+00$ & $0.0 E+00$ & $6.5 E+\infty 0$ & $2.4 \mathrm{E}-01$ & $2.8 \mathrm{E}+01$ & 2.2E-01 \\
\hline $\mathrm{Pu}-240$ & $1.1 E+00$ & $6.6 \mathrm{E}-02$ & $0.0 E+\infty 0$ & $0.0 E+\infty$ & $8.8 E-01$ & 5.7E-02 & $4.5 E+\infty 0$ & $5.5 \mathrm{E}-02$ \\
\hline Pu-241 & $1.4 \mathrm{E}+00$ & 8.7E-02. & $0.0 \mathrm{E}+00$ & $0.0 \mathrm{E}+00$ & $7.8 \mathrm{E}-01$ & $8.4 E-02$ & $0.0 \mathrm{E}+\infty 0$ & $0.0 \mathrm{E}+00$ \\
\hline Am-241 & nd & - & nd & - & nd & • & $1.5 \mathrm{E}+00$ & 1.1E-02 \\
\hline$P u-242$ & 2.5E-01 & $8.0 \mathrm{E}-02$ & $0.0 \mathrm{E}+\infty 0$ & $0.0 \mathrm{E}+00$ & $1.8 \mathrm{E}-01$ & 1.2E-02 & $1.1 \mathrm{E}+00$ & $4.2 \mathrm{E}-02$ \\
\hline & & & & & & & $E+02$ & \\
\hline $\begin{array}{l}\text { Total U } \\
\% \quad \text { U-235 }\end{array}$ & $\begin{array}{l}1.2 \mathrm{E}+02 \\
2.7 \mathrm{E}+00\end{array}$ & $\begin{array}{l}1.9 \mathrm{E}+00 \\
1.4 \mathrm{E}-01\end{array}$ & $\begin{array}{l}5.0 E+00 \\
8.9 E+00\end{array}$ & $\begin{array}{l}7.0 E-01 \\
1.5 E+\infty\end{array}$ & $\begin{array}{l}1.4 E+02 \\
2.8 E+00\end{array}$ & $3.1 \mathrm{E}-02$ & $2.4 \mathrm{E}+00$ & $3.4 \mathrm{E}-02$ \\
\hline$\%$ U.238 & $9.1 E+01$ & $3.4 \mathrm{E}-01$ & $7.6 \mathrm{E}+01$ & $3.5 E+\infty$ & $9.0 E+01$ & $4.2 \mathrm{E}-02$ & $9.2 E+01$ & 8.6E-02 \\
\hline Total Pu & $9.7 \mathrm{E}+00$ & 8.4E-01 & $0.0 E+\infty 0$ & $0.0 \mathrm{E}+00$ & $8.3 E+\infty 0$ & $3.6 \mathrm{E}-01$ & $1.4 \mathrm{E}+02$ & $3.5 E+00$ \\
\hline Eq. $\mathbf{U}$ & $3.7 E+01$ & $3.4 \mathrm{E}+00$ & 4.5E-01 & 8.3E-02 & $3.3 E+01$ & $1.3 E+\infty$ & $1.7 \mathrm{E}+02$ & $1.3 E+00$ \\
\hline $\mathrm{Cs} \cdot 137$ & nd & - & nd & 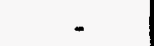 & nd & - & $3.8 E+00$ & $1.2 \mathrm{E}-01$ \\
\hline Eu-154 & nd & - & nd & - & nd & - & $2.6 \mathrm{E}-03$ & $7.9 \mathrm{E}-04$ \\
\hline
\end{tabular}


Appendix 2B.

\section{Calculated Weight Ratios for Tank 38H VDS Sample HTF.002}

\begin{tabular}{|c|c|c|c|c|c|c|c|c|}
\hline Weight Ratio & $\begin{array}{l}\text { Total } \\
\text { Average } \\
(\mu g / g \text { dried }\end{array}$ & $\begin{array}{l}\text { Sample } \\
\text { Std. Dev. } \\
\text { d sample) }\end{array}$ & $\begin{array}{l}\text { Liquid } \\
\text { Average } \\
(\mu g / g \text { liqu }\end{array}$ & $\begin{array}{l}\text { Fraction } \\
\text { Std. Dev. } \\
\text { id) }\end{array}$ & $\begin{array}{l}\text { Solids } \\
\text { Average } \\
\text { ( } \mu g / g \text { drie }\end{array}$ & $\begin{array}{l}\text { Fraction } \\
\text { Std. Dev. } \\
\text { d solids) }\end{array}$ & \multicolumn{2}{|c|}{$\begin{array}{l}\text { Insoluble Solids } \\
\text { Average Std. Dev. } \\
\text { ( } \mu \mathrm{g} / \mathrm{g} \text { insol. solids) }\end{array}$} \\
\hline $\mathrm{Al} / \mathrm{Eq} . \quad \mathrm{U}$ & $5.9 \mathrm{E}+02$ & $5.1 E+01$ & $2.2 E+04$ & $9.1 E+02$ & $3.8 E+02$ & $1.3 E+01$ & $2.1 E+02$ & $2.0 \mathrm{E}+00$ \\
\hline B/Eq. U & $5.2 \mathrm{E}+00$ & $5.5 E-01$ & $1.5 \mathrm{E}+02$ & $3.5 E+01$ & $2.0 \mathrm{E}+01$ & $1.0 \mathrm{E}+00$ & $4.6 E+\infty 0$ & $6.2 \mathrm{E}-02$ \\
\hline $\mathrm{Ba} / \mathrm{Eq} . \mathrm{U}$ & $7.0 \mathrm{E}+01$ & $1.2 \mathrm{E}+02$ & $<1.2 E+01$ & $3.5 E+00$ & $2.8 E+00$ & $9.2 \mathrm{E}-02$ & $1.9 \mathrm{E}+00$ & $2.4 \mathrm{E}-02$ \\
\hline $\mathrm{Ca} / \mathrm{Eq} \cdot \mathbf{U}$ & $3.7 E+02$ & $3.9 E+01$ & $6.4 E+00$ & $6.2 E+00$ & $5.2 \mathrm{E}+02$ & $1.9 \mathrm{E}+01$ & $<6.2 \mathrm{E}-03$ & $4.9 \mathrm{E}-05$ \\
\hline $\mathrm{Cd} / \mathrm{Eq} \cdot \mathrm{U}$ & $5.9 \mathrm{E}-01$ & $9.2 \mathrm{E}-02$ & $<5.9 E+00$ & $1.7 \mathrm{E}+00$ & $6.1 \mathrm{E}-01$ & 2.5E-02 & $4.3 \mathrm{E}-01$ & $9.6 \mathrm{E}-03$ \\
\hline Co/Eq. U & $6.2 \mathrm{E}-01$ & $1.3 \mathrm{E}-01$ & $\mid<2.5 \mathrm{E}+01$ & $7.1 E+00$ & $<2.4 \mathrm{E}-01$ & $9.5 \mathrm{E}-03$ & $2.2 \mathrm{E}-01$ & $1.3 \mathrm{E}-02$ \\
\hline $\mathrm{Cr} / \mathrm{Eq} \cdot \mathrm{U}$ & $1.5 E+02$ & $1.6 \mathrm{E}+01$ & $1.3 \mathrm{E}+03$ & $6.3 E+01$ & $1.8 \mathrm{E}+02$ & $6.2 \mathrm{E}+00$ & $5.6 E+01$ & $4.9 \mathrm{E}-01$ \\
\hline $\mathrm{Cu} / \mathrm{Eq}$. & $2.0 \mathrm{E}+00$ & $3.4 \mathrm{E}-01$ & $<2.7 \mathrm{E}+01$ & $7.9 E+00$ & $1.4 \mathrm{E}+00$ & $3.4 \mathrm{E}-02$ & $1.1 \mathrm{E}+00$ & $3.0 \mathrm{E}-02$ \\
\hline $\mathrm{Fe} / \mathrm{Eq}$. & $5.2 E+02$ & $5.2 E+01$ & $3.5 E+01$ & $7.3 E+00$ & $6.6 \mathrm{E}+02$ & $2.2 \mathrm{E}+01$ & $4.1 E+02$ & $4.8 E+00$ \\
\hline La/Eq. U & $5.6 \mathrm{E}-01$ & $7.8 \mathrm{E}-02$ & $<8.5 E+01$ & $2.5 E+01$ & $\mid<8.1 \mathrm{E}-01$ & 3.3E-02 & $\mid<2.0 \mathrm{E}-01$ & $1.6 \mathrm{E}-03$ \\
\hline Li/Eq. U & $2.2 \mathrm{E}+00$ & $3.5 \mathrm{E}-01$ & $<2.6 \mathrm{E}+01$ & $7.8 E+00$ & $2.0 \mathrm{E}+00$ & $9.0 \mathrm{E}-02$ & $1.6 \mathrm{E}+00$ & $2.1 \mathrm{E}-02$ \\
\hline $\mathbf{M g} / \mathbf{E q}$. & $2.9 E+01$ & $2.9 \mathrm{E}+00$ & $2.2 \mathrm{E}+00$ & $4.0 \mathrm{E}-01$ & $3.6 \mathrm{E}+01$ & $1.3 \mathrm{E}+00$ & $2.3 E+01$ & $2.4 \mathrm{E}-01$ \\
\hline Mn/Eq. U & $4.2 E+02$ & $4.4 \mathrm{E}+01$ & $4.2 E+01$ & $2.3 \mathrm{E}+0 \mathrm{I}$ & $5.2 E+02$ & $1.9 \mathrm{E}+01$ & $\mid<1.0 \mathrm{E}-02$ & $7.9 E-05$ \\
\hline Mo/Eq. & $1.8 \mathrm{E}+00$ & $2.4 \mathrm{E}-01$ & $4.8 E+01$ & $5.8 \mathrm{E}+00$ & 8.1E-01 & 2.5E-02 & $1.3 \mathrm{E}-01$ & $1.2 \mathrm{E}-02$ \\
\hline $\mathrm{Na} / \mathrm{Eq} \cdot \mathrm{U}$ & $9.1 E+03$ & $9.4 \mathrm{E}+02$ & $4.1 E+05$ & $1.7 \mathrm{E}+04$ & $6.5 \mathrm{E}+03$ & $2.3 E+02$ & $1.2 \mathrm{E}+03$ & $1.0 E+01$ \\
\hline $\mathrm{Ni} / \mathrm{Eq}$. & $4.5 \mathrm{E}+01$ & $4.8 E+00$ & $<2.9 \mathrm{E}+01$ & $8.8 E+\infty$ & $5.6 \mathrm{E}+01$ & $1.8 \mathrm{E}+00$ & $3.6 E+01$ & $3.7 E-01$ \\
\hline P/Eq. U & $1.1 \mathrm{E}+02$ & $1.1 E+01$ & $1.2 \mathrm{E}+03$ & $2.3 E+02$ & $1.2 E+02$ & $3.0 \mathrm{E}+00$ & $7.6 E+01$ & $7.1 \mathrm{E}-01$ \\
\hline $\mathrm{Pb} / \mathbf{E q} \cdot \mathbf{U}$ & $4.4 E+00$ & 7.2E-01 & $<1.6 \mathrm{E}+02$ & 4.7E+01 & $2.6 \mathrm{E}+00$ & $5.7 \mathrm{E}-01$ & $1.9 E+00$ & $1.2 \mathrm{E}-01$ \\
\hline Sn/Eq. & $6.0 \mathrm{E}-01$ & $8.9 \mathrm{E}-02$ & $<2.9 E+01$ & $8.3 E+\infty 0$ & $2.8 \mathrm{E}-01$ & $1.5 \mathrm{E}-02$ & $1.7 E+01$ & $6.6 \mathrm{E}+\infty 0$ \\
\hline $\mathrm{Sr} / \mathrm{Eq} \cdot \mathrm{U}$ & $1.4 E+00$ & $1.6 \mathrm{E}-01$ & $<4.9 E+00$ & $1.4 E+00$ & $1.6 \mathrm{E}+00$ & $5.0 \mathrm{E}-02$ & $9.7 \mathrm{E}-01$ & $1.2 \mathrm{E}-02$ \\
\hline Ti/Eq. $\mathbf{U}$ & $1.9 E+00$ & $3.4 \mathrm{E}-01$ & $<1.9 E+01$ & $5.5 \mathrm{E}+00$ & $1.7 E+00$ & 3.0E-02 & $2.2 \mathrm{E}+00$ & $4.6 \mathrm{E}-01$ \\
\hline V/Eq. U & $6.3 \mathrm{E}-01$ & $1.7 \mathrm{E}-01$ & $<2.1 E+01$ & $6.1 E+\infty 0$ & $<2.0 \mathrm{E}-01$ & $8.0 \mathrm{E}-03$ & $<5.0 \mathrm{E}-02$ & $3.9 E-04$ \\
\hline $\mathrm{Zn} / \mathrm{Eq} \cdot \mathbf{U}$ & $4.6 \mathrm{E}+00$ & $6.9 \mathrm{E}-01$ & $1.0 \mathrm{E}+02$ & $5.7 E+00$ & $5.3 E+00$ & $1.9 \mathrm{E}-01$ & $4.1 E+\infty 0$ & $3.6 \mathrm{E}-02$ \\
\hline Zrr/Eq. U & $5.1 \mathrm{E}-0 \mathrm{l}$ & $2.0 \mathrm{E}-01$ & $\mid<2.7 \mathrm{E}+01$ & $7.8 E+00$ & $\mid<2.5 \mathrm{E}-01$ & $1.0 \mathrm{E}-02$ & $\mid<6.4 \mathrm{E}-02$ & $5.0 \mathrm{E}-04$ \\
\hline
\end{tabular}


Appendix 3A.

\section{Complete ICP-ES and ICP-MS Results for Tank 38H Saltcake Sample} HTF-003

\begin{tabular}{|c|c|c|c|c|c|c|}
\hline Element & \multicolumn{2}{|c|}{$\begin{array}{c}\text { Total Sample } \\
\text { Average Std. Dev. } \\
(\mu \mathrm{g} / \mathrm{g} \text { dried sample }) \\
\end{array}$} & \multicolumn{2}{|c|}{$\begin{array}{cc}\text { Soluble } & \text { Salt } \\
\text { Average } & \text { Std. Dev. } \\
\text { ( } \mu g / g \text { salt })\end{array}$} & \multicolumn{2}{|c|}{$\begin{array}{c}\text { Insoluble Solids } \\
\text { Average Std. Dev. } \\
\text { ( } \mu \mathrm{g} / \mathrm{g} \text { insol. solids) }\end{array}$} \\
\hline A I & - $2.1 E+03$ & $4.0 E+02$ & $2.5 E+03$ & $7.7 \mathrm{E}+01$ & $1.5 E+04$ & $6.7 E+02$ \\
\hline B & $<5.0 \mathrm{E}+01$ & $3.1 E+00$ & $<1.7 \mathrm{E}+01$ & $6.0 E+\infty 0$ & $<3.6 \mathrm{E}+02$ & $0.0 E+00$ \\
\hline $\mathbf{B a}$ & $<7.8 \mathrm{E}+00$ & $3.6 \mathrm{E}-01$ & $<3.6 \mathrm{E}+00$ & $1.8 E+00$ & $<5.7 E+01$ & $0.0 \mathrm{E}+00$ \\
\hline $\mathrm{Ca}$ & $5.4 \mathrm{E}+01$ & $8.0 \mathrm{E}+00$ & $<4.8 \mathrm{E}-01$ & 1.1E-03 & $1.0 \mathrm{E}+04$ & $3.2 E+02$ \\
\hline Cd & $<3.8 \mathrm{E}+00$ & $1.8 \mathrm{E}-01$ & $<1.2 \mathrm{E}+\infty 0$ & $1.4 \mathrm{E}-01$ & $<2.8 \mathrm{E}+01$ & $0.0 \mathrm{E}+\infty 0$ \\
\hline Co & $<1.6 \mathrm{E}+01$ & $7.4 \mathrm{E}-01$ & $<5.0 \mathrm{E}+00$ & $1.6 \mathrm{E}-01$ & $<1.2 \mathrm{E}+02$ & $0.0 E+00$ \\
\hline $\mathrm{Cr}$ & $1.2 \mathrm{E}+02$ & $2.3 E+01$ & $4.9 E+01$ & $5.0 E+00$ & $1.4 \mathrm{E}+04$ & $4.2 E+02$ \\
\hline $\mathbf{C u}$ & $<1.7 \mathrm{E}+01$ & 8.1E-01 & $<6.9 \mathrm{E}+00$ & $2.3 E+00$ & $1.8 E+02$ & $0.0 \mathrm{E}+00$ \\
\hline $\mathrm{Fe}$ & $2.6 \mathrm{E}+02$ & $1.0 \mathrm{E}+02$ & $<4.2 \mathrm{E}+00$ & $1.1 E+00$ & 2.7E+04 & $8.9 E+02$ \\
\hline La & $<5.5 \mathrm{E}+01$ & $2.5 \mathrm{E}+00$ & $<1.9 \mathrm{E}+01$ & $3.1 E+\infty 0$ & $<4.0 \mathrm{E}+02$ & $0.0 \mathrm{E}+\infty 0$ \\
\hline $\mathbf{L} \mathbf{i}$ & $<1.8 \mathrm{E}+01$ & $8.6 \mathrm{E}-01$ & $<7.4 \mathrm{E}+00$ & $3.4 \mathrm{E}+00$ & $<1.3 \mathrm{E}+02$ & $0.0 \mathrm{E}+00$ \\
\hline $\mathbf{M g}$ & $1.3 \mathrm{E}+01$ & $1.3 E+00$ & $<4.4 \mathrm{E}-01$ & 4.7E-02 & $2.3 E+03$ & $7.7 E+01$ \\
\hline $\mathbf{M n}$ & $3.7 \mathrm{E}+02$ & $4.4 \mathrm{E}+01$ & $<1.6 \mathrm{E}+00$ & $1.8 E+00$ & $5.6 \mathrm{E}+04$ & $1.8 E+03$ \\
\hline Mo & $<6.4 \mathrm{E}+00$ & $3.0 \mathrm{E}-01$ & $<4.2 \mathrm{E}+00$ & $3.2 \mathrm{E}+00$ & $<4.7 \mathrm{E}+01$ & $0.0 \mathrm{E}+00$ \\
\hline $\mathrm{Na}$ & $3.0 \mathrm{E}+05$ & $9.1 \mathrm{E}+03$ & $3.4 \mathrm{E}+05$ & $8.0 E+03$ & $1.8 E+05$ & $5.7 E+03$ \\
\hline $\mathbf{N i}$ & $<2.0 \mathrm{E}+01$ & $9.8 \mathrm{E}-01$ & $<7.0 \mathrm{E}+00$ & $1.8 E+\infty 0$ & $7.9 E+02$ & $2.8 E+01$ \\
\hline $\mathbf{P}$ & $1.9 \mathrm{E}+02$ & $3.3 \mathrm{E}+01$ & $2.4 E+02$ & $9.4 E+00$ & $5.7 E+02$ & $6.0 \mathrm{E}+01$ \\
\hline $\mathbf{P b}$ & $<1.0 \mathrm{E}+02$ & $4.9 \mathrm{E}+00$ & $<3.2 \mathrm{E}+01$ & $6.4 \mathrm{E}-01$ & $<7.7 \mathrm{E}+02$ & $0.0 \mathrm{E}+00$ \\
\hline S n & $<1.9 \mathrm{E}+01$ & $8.6 \mathrm{E}-01$ & $<7.8 \mathrm{E}+00$ & $3.3 \mathrm{E}+00$ & $<1.4 \mathrm{E}+02$ & $0.0 \mathrm{E}+00$ \\
\hline $\mathbf{S r}$ & $<3.2 \mathrm{E}+00$ & $1.5 \mathrm{E}-01$ & $<1.5 \mathrm{E}+00$ & $7.5 \mathrm{E}-01$ & $<2.4 \mathrm{E}+01$ & $0.0 \mathrm{E}+00$ \\
\hline $\mathbf{T} \mathbf{i}$ & $<1.3 \mathrm{E}+01$ & $6.1 \mathrm{E}-01$ & $<4.9 E+00$ & $1.7 \mathrm{E}+00$ & $<9.8 E+01$ & $0.0 \mathrm{E}+00$ \\
\hline V & $<1.3 \mathrm{E}+01$ & $6.2 \mathrm{E}-01$ & $<5.9 E+\infty 0$ & $2.7 E+\infty 0$ & $<9.9 E+01$ & $0.0 E+00$ \\
\hline $\mathbf{Z n}$ & $1.9 \mathrm{E}+01$ & $4.5 E+00$ & $2.6 \mathrm{E}+00$ & $5.0 \mathrm{E}-01$ & $2.1 E+02$ & $3.2 \mathrm{E}+01$ \\
\hline $\mathbf{Z r}_{\mathbf{r}}$ & $<1.7 \mathrm{E}+01$ & 8.0E-01 & $<7.6 \mathrm{E}+00$ & $3.4 \mathrm{E}+\infty 0$ & $<1.3 E+02$ & $0.0 \mathrm{E}+00$ \\
\hline \multicolumn{7}{|l|}{ Isotope } \\
\hline U-233 & $0.0 E+00$ & $0.0 \mathrm{E}+00$ & $1.4 \mathrm{E}-03$ & $2.0 \mathrm{E}-03$ & 5.7E-02 & $8.0 \mathrm{E}-02$ \\
\hline$U-234$ & $3.0 \mathrm{E}-01$ & $2.8 \mathrm{E}-02$ & $2.6 \mathrm{E}-01$ & 7.5E-03 & $8.3 E+00$ & 8.0E-02 \\
\hline$U .235$ & $1.1 \mathrm{E}-01$ & $4.6 \mathrm{E}-03$ & $8.8 \mathrm{E}-02$ & 4.6E-03 & $3.1 E+\infty 0$ & 8.0E-02 \\
\hline U-236 & $5.0 \mathrm{E}-02$ & $1.7 \mathrm{E}-02$ & 3.4E-02 & $3.2 \mathrm{E}-03$ & $1.2 \mathrm{E}+\infty 0$ & $0.0 \mathrm{E}+00$ \\
\hline $\mathrm{Np} \cdot 237$ & $1.0 \mathrm{E}-01$ & $1.4 \mathrm{E}-02$ & $5.8 \mathrm{E}-02$ & $8.8 \mathrm{E}-03$ & $2.4 E+\infty 0$ & $8.0 \mathrm{E}-02$ \\
\hline U-238 & $3.4 E+\infty 0$ & $8.4 \mathrm{E}-02$ & $2.0 \mathrm{E}+00$ & 4.4E-02 & $1.7 E+02$ & $3.3 E+00$ \\
\hline $\mathrm{Pu-238}$ & nd & - & nd & - & nd & - \\
\hline $\mathrm{Pu}-239$ & $7.8 \mathrm{E}-01$ & 9.2E-02 & $9.4 \mathrm{E}-03$ & $0.00 E+00$ & $1.5 E+01$ & 4.0E-01 \\
\hline $\mathrm{Pu}-240$ & $5.9 \mathrm{E}-02$ & 2.1E-02 & $0.0 \mathrm{E}+00$ & $0.0 \mathrm{E}+\infty$ & $2.0 \mathrm{E}+00$ & $8.0 \mathrm{E}-02$ \\
\hline $\mathrm{Pu}-241$ & $8.0 \mathrm{E}-03$ & 3.2E-03 & $0.0 \mathrm{E}+00$ & $0.0 \mathrm{E}+00$ & $6.8 \mathrm{E}-01$ & $0.0 \mathrm{E}+\infty 0$ \\
\hline $\mathrm{Pu}-242$ & 4.1E-03 & 3.5E-03 & $0.0 \mathrm{E}+\infty 0$ & $0.0 E+\infty$ & $3.4 \mathrm{E}-01$ & $0.0 \mathrm{E}+00$ \\
\hline Total $\mathbf{U}$ & $3.9 \mathrm{E}+00$ & $1.1 \mathrm{E}-01$ & $2.4 \mathrm{E}+00$ & $3.7 \mathrm{E}-02$ & $1.8 \mathrm{E}+02$ & $3.5 E+\infty 0$ \\
\hline$\%$ U.235 & $2.9 \mathrm{E}+00$ & 7.4E-02 & $3.6 \mathrm{E}+00$ & $2.5 \mathrm{E}-01$ & $1.7 E+\infty$ & $1.1 \mathrm{E}-02$ \\
\hline$\% \quad$ U-238 & $8.8 \mathrm{E}+01$ & $1.0 \mathrm{E}+00$ & $8.4 \mathrm{E}+01$ & $5.4 \mathrm{E}-01$ & $9.3 E+01$ & 4.1E-03 \\
\hline Total Pu & 8.5E-01 & $1.1 \mathrm{E}-01$ & $9.4 \mathrm{E}-03$ & $0.0 \mathrm{E}+00$ & $1.8 \mathrm{E}+01$ & $3.2 \mathrm{E}-01$ \\
\hline Eq. U & $3.3 E+00$ & $3.6 \mathrm{E}-01$ & $1.3 \mathrm{E}-01$ & 2.7E-03 & $6.4 \mathrm{E}+01$ & $1.8 \mathrm{E}+00$ \\
\hline
\end{tabular}


Appendix 3B.

Calculated Weight Ratios for Tank 38H Saltcake Sample HTF-003

\begin{tabular}{|c|c|c|c|c|c|c|}
\hline \multirow[b]{2}{*}{ Weight } & Total & Sample & \multicolumn{2}{|c|}{ Soluble Salt } & Insoluble & Solids \\
\hline & Average & Std. Dev. & Average & Std. Dev. & Average & Std. Dev. \\
\hline $\mathrm{Al} / \mathrm{Eq} . \mathrm{U}$ & $6.8 E+02$ & $1.5 E+02$ & $2.5 E+04$ & $1.8 E+03$ & $2.4 E+02$ & $4.0 \mathrm{E}+00$ \\
\hline B/Eq. U & $<1.6 \mathrm{E}+01$ & $1.6 \mathrm{E}+00$ & $<1.7 \mathrm{E}+02$ & $7.2 E+01$ & $<5.6 \mathrm{E}+00$ & $1.5 \mathrm{E}-01$ \\
\hline Ba/Eq. U & $<2.5 \mathrm{E}+00$ & 2.5E-01 & $<3.7 \mathrm{E}+01$ & 2. $1 E+01$ & $<9.0 \mathrm{E}-01$ & $2.5 \mathrm{E}-02$ \\
\hline $\mathrm{Ca} / \mathrm{Eq} \cdot \mathrm{U}$ & $1.8 \mathrm{E}+01$ & $4.5 \mathrm{E}+00$ & $<4.6 E+00$ & $1.6 \mathrm{E}-01$ & $1.6 \mathrm{E}+02$ & $6.6 \mathrm{E}-01$ \\
\hline $\mathrm{Cd} / \mathrm{Eq} \cdot \mathrm{U}$ & $<1.2 \mathrm{E}+00$ & $1.2 \mathrm{E}-01$ & $<1.2 \mathrm{E}+01$ & $1.9 E+00$ & $<4.4 \mathrm{E}-01$ & $1.2 \mathrm{E}-02$ \\
\hline Co/Eq. U & $<5.1 E+00$ & $5.0 E-01$ & $<4.8 E+0 \mathrm{l}$ & $3.5 E+\infty 0$ & $<1.8 E+00$ & $5.1 \mathrm{E}-02$ \\
\hline $\mathrm{Cr} / \mathrm{Eq} . \mathrm{U}$ & $3.9 E+01$ & $8.3 E+\infty 0$ & $4.8 E+02$ & $7.2 E+01$ & $2.2 E+02$ & $5.3 \mathrm{E}-01$ \\
\hline $\mathrm{Cu} / \mathrm{Eq} \cdot \mathrm{U}$ & $<5.5 \mathrm{E}+00$ & $5.5 \mathrm{E}-01$ & $<6.9 \mathrm{E}+01$ & $2.7 \mathrm{E}+01$ & $2.7 E+\infty 0$ & $7.5 \mathrm{E}-02$ \\
\hline $\mathrm{Fe} / \mathrm{Eq} . \mathrm{U}$ & 8.3E+01 & $2.9 \mathrm{E}+01$ & $<4.1 E+01$ & $1.3 E+01$ & $4.3 E+02$ & $2.2 E+\infty$ \\
\hline La/Eq. U & $<1.7 \mathrm{E}+01$ & $1.7 \mathrm{E}+00$ & $<1.8 E+02$ & $4.0 E+01$ & $<6.3 E+00$ & $1.7 \mathrm{E}-01$ \\
\hline Li/Eq. U & $<5.8 E+00$ & $5.6 \mathrm{E}-01$ & $<7.5 \mathrm{E}+01$ & $3.9 E+01$ & $<2.1 E+00$ & $5.7 \mathrm{E}-02$ \\
\hline Mg/Eq. U & 4.3E+00 & $7.9 \mathrm{E}-01$ & $<4.3 E+\infty 0$ & $6.7 E-01$ & $3.6 \mathrm{E}+01$ & $2.0 \mathrm{E}-01$ \\
\hline $\mathbf{M n} / \mathbf{E q} \cdot \mathrm{U}$ & $1.2 \mathrm{E}+02$ & $2.2 E+01$ & $<1.7 E+01$ & $1.3 E+01$ & 8.7E+02 & 4.7E+00 \\
\hline Mo/Eq. U & $<2.0 \mathrm{E}+00$ & 2.0E-01 & $<4.4 E+01$ & $3.7 \mathrm{E}+01$ & $<7.4 \mathrm{E}-01$ & $2.0 \mathrm{E}-02$ \\
\hline $\mathrm{Na} / \mathrm{Eq} \cdot \mathrm{U}$ & $9.7 E+04$ & $1.4 E+04$ & $3.2 E+06$ & $2.6 E+04$ & $2.9 \mathrm{E}+03$ & $1.1 \mathrm{E}+01$ \\
\hline Ni/Eq. U & $<6.5 \mathrm{E}+00$ & $6.2 \mathrm{E}-01$ & $<6.9 \mathrm{E}+01$ & 2.3E+01 & $1.2 \mathrm{E}+01$ & $7.7 \mathrm{E}-01$ \\
\hline P/Eq. U & $6.3 \mathrm{E}+01$ & $1.8 E+01$ & 2.4E+03 & $1.9 \mathrm{E}+02$ & $8.9 E+\infty$ & $1.2 E+\infty$ \\
\hline Pb/Eq. U & $<3.3 \mathrm{E}+01$ & $3.3 E+00$ & $<3.1 E+02$ & $1.8 E+01$ & $<1.2 E+01$ & $3.3 E-01$ \\
\hline Sn/Eq. U & $<5.9 \mathrm{E}+00$ & $5.9 \mathrm{E}-01$ & $<7.9 \mathrm{E}+01$ & $3.7 \mathrm{E}+01$ & $<2.1 \mathrm{E}+00$ & $5.9 \mathrm{E}-02$ \\
\hline Sr/Eq. U & $<1.0 \mathrm{E}+00$ & $1.0 \mathrm{E}-01$ & $<1.5 \mathrm{E}+01$ & 8.7E+00 & $<3.7 \mathrm{E}-01$ & $1.0 \mathrm{E}-02$ \\
\hline Ti/Eq. $\mathbf{U}$ & $<4.2 \mathrm{E}+00$ & 4.2E-01 & $<4.8 \mathrm{E}+01$ & $2.0 \mathrm{E}+01$ & $<1.5 E+\infty 0$ & $4.2 \mathrm{E}-02$ \\
\hline V/Eq. U & $<4.3 \mathrm{E}+00$ & $4.2 \mathrm{E}-01$ & $<6.0 \mathrm{E}+01$ & $3.1 \mathrm{E}+01$ & $<1.5 E+00$ & $4.2 \mathrm{E}-02$ \\
\hline $\mathrm{Zn} / \mathbf{E q} \cdot \mathbf{U}$ & $6.1 E+\infty$ & $9.2 \mathrm{E}-01$ & $2.6 E+01$ & $6.0 E+00$ & $3.3 \mathrm{E}+\infty$ & 4.1E-01 \\
\hline$Z_{r} /$ Eq. $U$ & $<5.5 \mathrm{E}+00$ & $5.4 \mathrm{E}-01$ & $<7.7 \mathrm{E}+01$ & $4.0 \mathrm{E}+01$ & $<2.0 \mathrm{E}+00$ & $5.4 \mathrm{E}-02$ \\
\hline
\end{tabular}


Apprendix 4A.

Complete ICP-ES and ICP-MS Results for Tank 38H VDS Sample HTF -004

\begin{tabular}{|c|c|c|c|c|c|c|c|c|c|c|}
\hline Element & $\begin{array}{l}\text { Total S } \\
\text { Average } \\
(\mu g / g \text { drie }\end{array}$ & $\begin{array}{l}\text { Sample } \\
\text { Std. Dev. } \\
\text { ed sample) }\end{array}$ & $\begin{array}{r}\text { Liquid } \\
\text { Average } \\
(\mu g / g\end{array}$ & $\begin{array}{l}\text { Fraction } \\
\text { Std. Dev. } \\
\text { liquid) }\end{array}$ & $\begin{array}{l}\text { Solids } \\
\text { Average } \\
(\mu \mathrm{g} / \mathrm{g} d r\end{array}$ & $\begin{array}{l}\text { raction } \\
\text { Std. Dev. } \\
\text { ed solids) }\end{array}$ & & $\begin{array}{l}\text { Insolub } \\
\text { Average } \\
(\mu \mathrm{g} / \mathrm{g} \text { in }\end{array}$ & $\begin{array}{l}\text { Solids } \\
\text { Std. Dev. } \\
\text { ol. solids) }\end{array}$ & $s$ \\
\hline Al & $1.4 \mathrm{E}+04$ & $2.4 E+03$ & $9.2 E+03$ & $3.6 \mathrm{E}+02$ & $8.4 E+03$ & $1.6 \mathrm{E}+02$ & & $4.5 E+04$ & $6.1 E+02$ & 2 \\
\hline $\mathbf{B}$ & $<7.8 \mathrm{E}+01$ & $1.9 E+00$ & $6.6 \mathrm{E} \div 01$ & $2.0 E+01$ & $6.9 \mathrm{E}+02$ & $1.4 \mathrm{E}+01$ & & $6.9 E+02$ & $9.0 \mathrm{E}+00$ & 0 \\
\hline $\mathbf{B a}$ & $<1.3 \mathrm{E}+01$ & $1.3 \mathrm{E}+00$ & $<4.4 \mathrm{E}+00$ & $1.4 \mathrm{E}+00$ & $<4.0 \mathrm{E}+00$ & $0.0 \mathrm{E}+00$ & $<$ & $4.0 E+00$ & $0.0 \mathrm{E}+00$ & $?$ \\
\hline $\mathrm{Ca}$ & $2.5 E+02$ & $4.0 E+01$ & $5.5 \mathrm{E}+00$ & $7.7 \mathrm{E}+00$ & $4.6 E+02$ & $1.1 E+01$ & & $2.5 E+03$ & $3.3 E+01$ & 0 \\
\hline Cd & $<6.3 E+00$ & $6.5 \mathrm{E}-01$ & $<2.0 \mathrm{E}+00$ & $8.9 \mathrm{E}-01$ & $<2.0 \mathrm{E}+00$ & $0.0 \mathrm{E}+00$ & $<$ & $1.9 E+00$ & $3.0 \mathrm{E}-08$ & 3 \\
\hline $\mathrm{Co}_{0}$ & $<2.7 E+01$ & $2.7 \mathrm{E}+00$ & $<8.0 \mathrm{E}+00$ & $4.5 E+00$ & $<8.3 E+00$ & $0.0 \mathrm{E}+00$ & $<$ & $8.2 E+00$ & $1.2 \mathrm{E}-07$ & ? \\
\hline $\mathrm{Cr}$ & $4.0 \mathrm{E}+02$ & $6.6 \mathrm{E}+01$ & $1.8 \mathrm{E}+02$ & $4.6 \mathrm{E}+00$ & $4.1 E+02$ & $5.1 E+00$ & & $6.7 E+02$ & 9.1E+00 & 0 \\
\hline $\mathrm{Cu}$ & $<2.9 E+01$ & $3.0 \mathrm{E}+00$ & $<1.1 E+01$ & $1.2 E+\infty 0$ & $<9.0 \mathrm{E}+00$ & $0.0 \mathrm{E}+\infty 0$ & $<$ & $8.9 E+00$ & $0.0 \mathrm{E}+00$ & ! \\
\hline $\mathrm{Fe}$ & $2.3 E+02$ & $2.9 E+01$ & $2.3 E+01$ & $4.2 E+00$ & 4.7E+02 & $9.5 E+00$ & & $1.6 E+03$ & $2.0 E+01$ & 3 \\
\hline La & $<9.2 \mathrm{E}+01$ & $9.4 \mathrm{E}+00$ & $<2.7 \mathrm{E}+01$ & $1.6 \mathrm{E}+01$ & $<2.8 E+01$ & $0.0 E+00$ & $<$ & $2.8 \mathrm{E}+01$ & $4.8 E-07$ & : \\
\hline $\mathbf{L i}_{\mathbf{i}}$ & $<2.9 E+01$ & $2.9 E+00$ & $<9.5 E+00$ & $3.1 E+00$ & $<9.0 \mathrm{E}+00$ & $0.0 \mathrm{E}+\infty 0$ & $<$ & $8.7 E+00$ & $0.0 E+00$ & ! \\
\hline $\mathbf{M g}$ & $2.2 E+01$ & $3.6 \mathrm{E}+00$ & $<7.7 \mathrm{E}-01$ & $2.4 \mathrm{E}-01$ & $4.3 \mathrm{E}+01$ & $9.1 \mathrm{E}-01$ & & $1.5 E+02$ & $2.2 E+00$ & \\
\hline Mn & $9.4 \mathrm{E}+01$ & $1.6 \mathrm{E}+01$ & $1.6 \mathrm{E}+01$ & $1,2 \mathrm{E}+00$ & $1.7 \mathrm{E}+02$ & $5.1 E+\infty$ & & $5.7 \mathrm{E}+02$ & $8.5 E+00$ & J \\
\hline Mo & $2.2 \mathrm{E}+01$ & $8.6 E+00$ & $2.5 \mathrm{E}+0 \mathrm{I}$ & $4.1 E+00$ & $1.6 \mathrm{E}+01$ & $2.3 E+\infty 0$ & & $9.9 E+00$ & 4.7E-01 & : \\
\hline $\mathrm{Na}$ & $3.5 E+05$ & $5.5 E+04$ & $2.1 E+05$ & $2.9 E+03$ & $2.6 E+05$ & $4.9 E+03$ & & $2.7 \mathrm{E}+05$ & $3.9 E+03$ & 3 \\
\hline $\mathrm{Ni}$ & $4.2 E+01$ & $9.9 E+00$ & $<1.0 \mathrm{E}+01$ & $4.0 \mathrm{E}+00$ & $4.8 E+01$ & $5.5 E+\infty 0$ & & $2.4 E+02$ & $4.5 E+00$ & \\
\hline $\mathbf{P}$ & $1.5 E+03$ & $3.4 \mathrm{E}+02$ & $7.2 \mathrm{E}+02$ & $7.3 E+01$ & $1.4 E+03$ & $3.0 \mathrm{E}+01$ & & $3.7 E+02$ & 2.7E+00 & 3 \\
\hline $\mathbf{P b}$ & $<1.8 \mathrm{E}+02$ & $1.8 \mathrm{E}+01$ & $<5.9 \mathrm{E}+01$ & $2.0 \mathrm{E}+01$ & $<5.4 \mathrm{E}+01$ & $0.0 \mathrm{E}+\infty 0$ & $<$ & $5.4 E+01$ & $9.5 E-07$ & \\
\hline Sn & $<3.1 E+01$ & $3.2 E+\infty 0$ & $<1.1 E+01$ & $2.8 E+00$ & $<9.6 \mathrm{E}+00$ & $0.0 \mathrm{E}+00$ & & $3.5 E+03$ & $1.0 E+03$ & 1 \\
\hline Sr & $<5.2 \mathrm{E}+00$ & 5.4E-01 & $<1.7 \mathrm{E}+00$ & $6.4 \mathrm{E}-01$ & $<1.7 \mathrm{E}+\infty$ & $0.0 \mathrm{E}+\infty 0$ & $<$ & $1.6 E+00$ & $0.0 \mathrm{E}+00$ & ; \\
\hline $\mathrm{Ti}$ & $<1.9 \mathrm{E}+01$ & $2.0 E+00$ & $<6.4 \mathrm{E}+00$ & $2.9 E+00$ & $<6.4 E+\infty 0$ & $8.4 \mathrm{E}-08$ & $<$ & $9.6 E+00$ & $1.7 \mathrm{E}-07$ & $:$ \\
\hline $\mathbf{v}$ & $<2.5 E+01$ & $1.5 E+00$ & $<7.5 \mathrm{E}+00$ & $2.6 \mathrm{E}+00$ & $<6.9 E+\infty 0$ & $0.0 \mathrm{E}+00$ & $<$ & $6.8 E+00$ & $0.0 \mathrm{E}+00$ & ! \\
\hline $\mathbf{Z}_{\mathbf{n}}$ & $2.2 \mathrm{E}+01$ & $1.2 \mathrm{E}+01$ & $2.0 \mathrm{E}+01$ & $2.0 \mathrm{E}+00$ & $6.4 E+\infty$ & 2.1E+00 & & $1.1 E+02$ & $2.3 E+00$ & \\
\hline $\mathbf{Z r}$ & $<2.9 \mathrm{E}+01$ & $3.0 E+\infty 0$ & $<9.4 \mathrm{E}+00$ & $3.7 E+\infty 0$ & $<8.9 E+\infty 0$ & $0.0 \mathrm{E}+00$ & & $1.2 \mathrm{E}+01$ & $1.7 E+\infty 0$ & \\
\hline \multicolumn{11}{|l|}{ Isotope } \\
\hline U-233 & $0.0 \mathrm{E}+00$ & $0.0 \mathrm{E}+00$ & $6.6 \mathrm{E}-03$ & $5.8 \mathrm{E}-03$ & $1.1 \mathrm{E}-02$ & $1.8 \mathrm{E}-02$ & & $0.0 \mathrm{E}+00$ & $0.0 \mathrm{E}+00$ & \\
\hline U.234 & $1.7 E+00$ & $2.8 \mathrm{E}-01$ & $9.7 \mathrm{E}-01$ & 1.2E-01 & $1.5 \mathrm{E}+00$ & $4.0 \mathrm{E}-02$ & & $1.4 E+00$ & $1.5 \mathrm{E}-01$ & \\
\hline U.235 & $5.7 \mathrm{E}-01$ & $1.4 \mathrm{E}-01$ & $3.2 \mathrm{E}-01$ & 4.0E-02 & $5.4 \mathrm{E}-01$ & $1.6 \mathrm{E}-02$ & & $5.6 \mathrm{E}-01$ & $1.9 E-02$ & \\
\hline $\mathrm{U}-236$ & $2.1 E-01$ & $2.7 \mathrm{E}-02$ & $1.2 \mathrm{E}-01$ & $1.1 E-02$ & 2.0E-01 & 2.7E-02 & & $2.4 \mathrm{E}-01$ & 3.7E-02 & \\
\hline $\mathrm{Np-237}$ & 5.0E-01 & $1.2 \mathrm{E}-01$ & 2.9E-01 & $6.8 E-02$ & $4.8 \mathrm{E}-01$ & $3.7 \mathrm{E}-02$ & & $1.6 E+\infty 0$ & $1.2 E-01$ & \\
\hline $\mathrm{U}-238$ & $1.2 \mathrm{E}+01$ & $2.4 \mathrm{E}+00$ & $4.2 \mathrm{E}+\infty 0$ & $5.7 \mathrm{E}-01$ & $1.8 \mathrm{E}+01$ & $2.4 \mathrm{E}-01$ & & $3.5 E+01$ & 8.5E-01 & \\
\hline$P u-238$ & nd & - & nd & - & nd & - & & $1.1 E+01$ & $5.2 \mathrm{E}-01$ & \\
\hline Pu.239 & $3.8 \mathrm{E}-01$ & $7.5 \mathrm{E}-02$ & $1.7 \mathrm{E}-02$ & $1.9 E-02$ & $7.0 \mathrm{E}-01$ & $1.6 \mathrm{E}-02$ & & $3.8 \mathrm{E}+\infty$ & $1.7 \mathrm{E}-01$ & \\
\hline $\mathrm{Pu}-\mathbf{2 4 0}$ & $0.0 \mathrm{E}+00$ & $0.0 \mathrm{E}+00$ & $2.9 \mathrm{E}-03$ & 2.5E-03 & $9.2 \mathrm{E}-02$ & $1.2 \mathrm{E}-02$ & & $6.4 \mathrm{E}-01$ & 4.4E-02 & \\
\hline$P u-241$ & $0.0 \mathrm{E}+\infty 0$ & $0.0 \mathrm{E}+00$ & $1.4 \mathrm{E}-03$ & 1.3E-03 & $3.6 \mathrm{E}-02$ & $6.2 \mathrm{E}-03$ & & $1.9 \mathrm{E}-01$ & $6.5 \mathrm{E}-02$ & \\
\hline Am-241 & nd & - & nd & - & nd & - & & $6.5 E+00$ & 2.2E-02 & \\
\hline $\mathrm{Pu} \cdot \mathbf{2 4 2}$ & $0.0 \mathrm{E}+00$ & $0.0 \mathrm{E}+00$ & 4.4E-04 & $7.6 \mathrm{E}-04$ & $0.0 \mathrm{E}+00$ & $0.0 \mathrm{E}+\infty 0$ & & $1.6 \mathrm{E}-01$ & $6.6 \mathrm{E}-02$ & \\
\hline Total $\mathbf{U}$ & $1.5 \mathrm{E}+01$ & $2.8 \mathrm{E}+00$ & $5.6 \mathrm{E}+00$ & $7.2 \mathrm{E}-01$ & $2.0 \mathrm{E}+01$ & $3.1 \mathrm{E}-01$ & & $3.8 E+01$ & $8.6 \mathrm{E}-01$ & \\
\hline$\% \quad U-235$ & $3.9 E+\infty 0$ & $2.2 \mathrm{E}-01$ & $5.7 \mathrm{E}+\infty 0$ & $3.3 E-01$ & $2.7 \mathrm{E}+00$ & $6.0 \mathrm{E}-02$ & & $1.5 E+00$ & $7.3 E-02$ & \\
\hline \% U.238 & $8.3 E+01$ & 3.4E-01 & $7.5 E+01$ & $1.1 E+\infty 0$ & $8.9 E+01$ & $1.9 \mathrm{E}-01$ & & $9.4 E+01$ & $3.6 \mathrm{E}-01$ & \\
\hline Total Pu & $3.8 \mathrm{E}-01$ & 7.5E-02 & $2.2 \mathrm{E}-02$ & $2.3 \mathrm{E}-02$ & 8.3E-01 & $3.3 \mathrm{E}-02$ & & $1.6 \mathrm{E}+01$ & $6.4 \mathrm{E}-01$ & \\
\hline Eq. U & $2.1 E+00$ & $4.4 \mathrm{E}-01$ & $4.0 \mathrm{E}-01$ & $9.4 \mathrm{E}-02$ & $3.5 E+\infty$ & $1.0 \mathrm{E}-01$ & & $1.7 E+01$ & $8.0 E-01$ & \\
\hline Cs-137 & nd & - & nd & - & nd & . & & $4.1 E+00$ & $3.2 \mathrm{E}-02$ & \\
\hline Eu-154 & nd & - & nd & $\therefore$ & nd & - & & $3.2 \mathrm{E}-04$ & $2.8 \mathrm{E}-04$ & \\
\hline
\end{tabular}


Appendix 5A.

Complete ICP-ES and ICP-MS Results for Tank 41H Saltcake Sample ITP.309 (41SC0696)

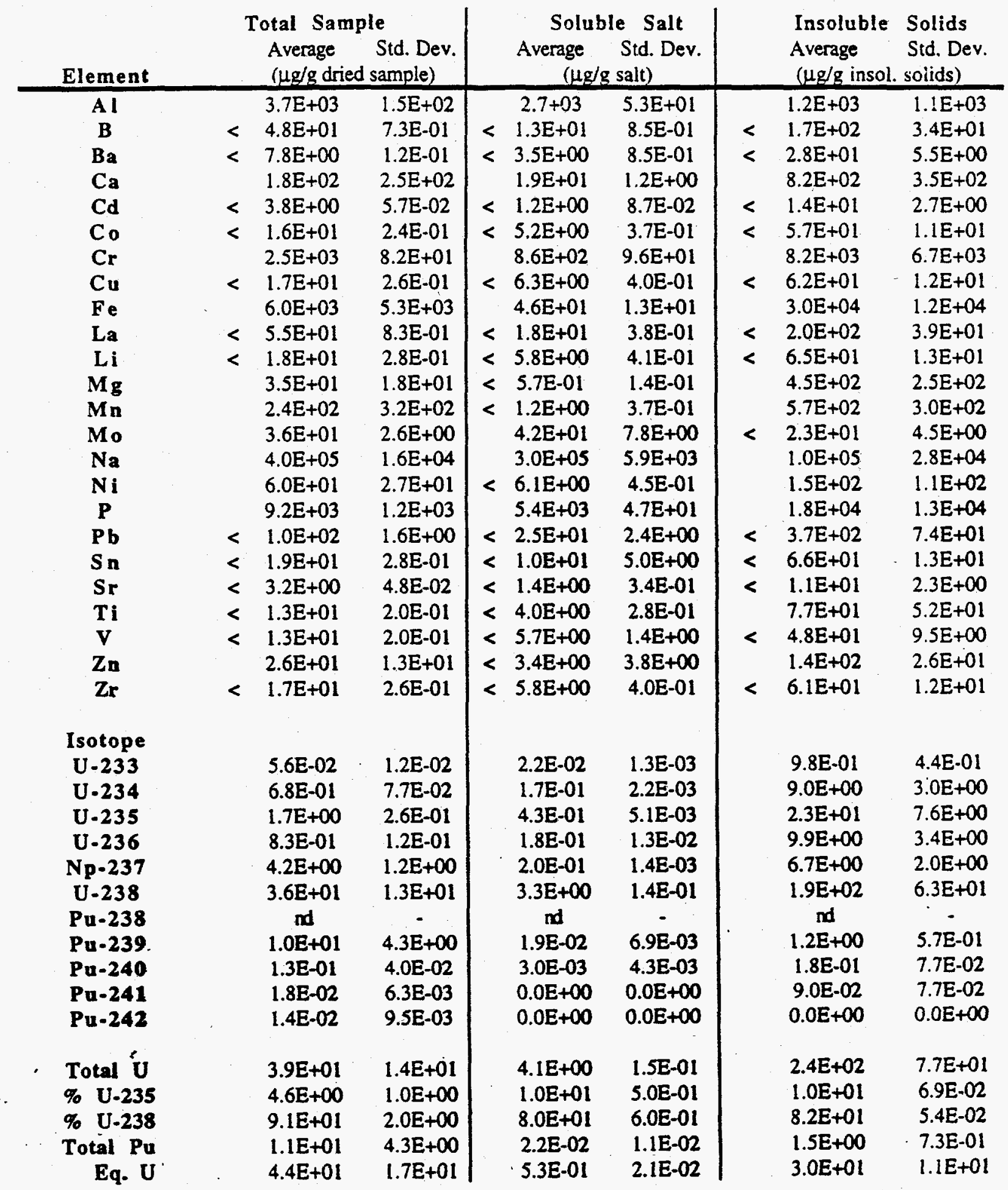


Appendix 5B.

\section{Calculated Weight Ratios for Tank $41 \mathrm{H}$ Saltcake Sample} ITP-309 (41SC0696

\begin{tabular}{|c|c|c|c|c|c|c|}
\hline Weight Ratio & $\begin{array}{l}\text { Total S } \\
\text { Average }\end{array}$ & $\begin{array}{l}\text { le } \\
\text { Std. Dev. }\end{array}$ & $\begin{array}{l}\text { Dissol } \\
\text { Average }\end{array}$ & $\begin{array}{l}\text { d Salt } \\
\text { Std. Dev. }\end{array}$ & $\begin{array}{l}\text { Insoluble } \\
\text { Average }\end{array}$ & $\begin{array}{l}\text { Solids } \\
\text { Std. Dev. }\end{array}$ \\
\hline Al/Eq. U & $9.3 E+01$ & $3.3 E+01$ & $5.1 E+03$ & $8.0 E+01$ & $3.6 \mathrm{E}+01$ & $2.5 E+01$ \\
\hline B/Eq. U & $<1.2 \mathrm{E}+00$ & 4.1E-01 & $<2.5 E+01$ & 7.0E-01 & $<6.0 \mathrm{E}+00$ & $1.0 \mathrm{E}+00$ \\
\hline $\mathrm{Ba} / \mathrm{Eq} . \mathrm{U}$ & $<2.0 \mathrm{E}-01$ & $6.7 \mathrm{E}-02$ & $<6.7 \mathrm{E}+00$ & $1.8 \mathrm{E}+\infty 0$ & $<9.7 \mathrm{E}-01$ & $1.6 \mathrm{E}-01$ \\
\hline $\mathrm{Ca} / \mathrm{Eq} \cdot \mathrm{U}$ & $5.4 \mathrm{E}+00$ & $8.0 \mathrm{E}+00$ & $3.6 \mathrm{E}+01$ & $3.5 \mathrm{E}+\infty$ & $2.7 E+01$ & $2.2 \mathrm{E}+00$ \\
\hline $\mathrm{Cd} / \mathrm{Eq} . \mathrm{U}$ & $<9.6 \mathrm{E}-02$ & $3.2 \mathrm{E}-02$ & $<2.2 \mathrm{E}+00$ & $8.5 \mathrm{E}-02$ & $<4.7 \mathrm{E}-01$ & $8.0 \mathrm{E}-02$ \\
\hline $\mathrm{Co} / \mathrm{Eq} . \mathrm{U}$ & $<4.0 \mathrm{E}-01$ & $1.4 \mathrm{E}-01$ & $<1.0 \mathrm{E}+01$ & $3.6 \mathrm{E}-01$ & $<2.0 \mathrm{E}+00$ & $3.4 \mathrm{E}-01$ \\
\hline $\mathrm{Cr} / \mathrm{Eq} \cdot \mathrm{U}$ & $6.3 E+01$ & $2.0 \mathrm{E}+01$ & $1.6 \mathrm{E}+03$ & $1.2 \mathrm{E}+02$ & $2.5 \mathrm{E}+02$ & $1.4 E+02$ \\
\hline $\mathrm{Cu} / \mathrm{Eq} \cdot \mathrm{U}$ & $<4.4 \mathrm{E}-01$ & $1.5 \mathrm{E}-01$ & $<1.2 E+01$ & $3.9 \mathrm{E}-01$ & $<2.2 \mathrm{E}+00$ & $3.6 \mathrm{E}-01$ \\
\hline $\mathrm{Fe} / \mathrm{Eq} . \mathrm{U}$ & $1.7 E+02$ & $1.8 \mathrm{E}+02$ & $8.8 E+01$ & $2.8 \mathrm{E}+01$ & $1.0 \mathrm{E}+03$ & $6.1 E+01$ \\
\hline La/Eq. U & $<1.4 E+00$ & 4.7E-01 & $<3.3 \mathrm{E}+01$ & $2.0 \mathrm{E}+00$ & $<6.9 E+00$ & $1.2 E+00$ \\
\hline Li/Eq. U & $<4.6 \mathrm{E}-01$ & $1.6 \mathrm{E}-01$ & $<1.1 E+01$ & 4.2E-01 & $<2.3 E+00$ & $3.8 \mathrm{E}-01$ \\
\hline Mg/Eq. U & $9.1 \mathrm{E}-01$ & $6.9 \mathrm{E}-01$ & $<1.1 E+\infty 0$ & $3.1 \mathrm{E}-01$ & $1.5 \mathrm{E}+01$ & $3.3 E+00$ \\
\hline $\mathrm{Mn} / \mathrm{Eq} \cdot \mathrm{U}$ & $7.2 E+\infty 0$ & $1.0 E+01$ & $<2.2 E+00$ & 7.7E-01 & $1.9 \mathrm{E}+01$ & $3.5 E+00$ \\
\hline Mo/Eq. U & $9.1 \mathrm{E}-01$ & 3.4E-01 & $8.0 \mathrm{E}+01$ & $1.7 E+01$ & $<8.0 \mathrm{E}-01$ & $1.3 \mathrm{E}-01$ \\
\hline $\mathrm{Na} / \mathrm{Eq} \cdot \mathrm{U}$ & $1.0 \mathrm{E}+04$ & $3.1 E+03$ & $5.8 E+05$ & $9.6 E+03$ & $3.6 E+03$ & $3.4 E+02$ \\
\hline Ni/Eq. $\mathbf{U}$ & $1.6 \mathrm{E}+00$ & $1.1 E+\infty$ & $<1.2 \mathrm{E}+01$ & $4.6 \mathrm{E}-01$ & $4.7 \mathrm{E}+\infty 0$ & $2.2 E+\infty$ \\
\hline P/Eq. U & $2.3 E+02$ & $5.2 E+01$ & $1.0 \mathrm{E}+04$ & $4.6 E+02$ & $5.8 E+02$ & $2.2 \mathrm{E}+02$ \\
\hline $\mathrm{Pb} / \mathbf{E q} . \mathrm{U}$ & $<2.6 \mathrm{E}+00$ & $8.9 \mathrm{E}-01$. & $<4.6 E+01$ & $2.3 E+00$ & $<1.3 \mathrm{E}+01$ & $2.2 \mathrm{E}+00$ \\
\hline Sn/Eq. U & $<4.7 \mathrm{E}-01$ & $1.6 \mathrm{E}-01$ & $<2.0 \mathrm{E}+01$ & $1.0 \mathrm{E}+01$ & $<2.3 \mathrm{E}+00$ & $3.9 \mathrm{E}-01$ \\
\hline $\mathrm{Sr} / \mathrm{Eq} . \mathrm{U}$ & $<8.1 E-02$ & 2.7E-02 & $<2.8 E+00$ & $7.3 \mathrm{E}-01$ & $<4.0 \mathrm{E}-01$ & $6.7 \mathrm{E}-02$ \\
\hline Ti/Eq. U & $<3.3 \mathrm{E}-01$ & $1.1 \mathrm{E}-01$ & $<7.6 \mathrm{E}+\infty 0$ & 2.7E-01 & $2.5 E+\infty 0$ & $8.8 \mathrm{E}-01$ \\
\hline V/Eq. U & $<3.4 \mathrm{E}-01$ & $1.1 \mathrm{E}-01$ & $<1.1 \mathrm{E}+01$ & $3.1 E+00$ & $<1.7 \mathrm{E}+\infty 0$ & $2.8 \mathrm{E}-01$ \\
\hline Zn/Eq. U & $7.0 \mathrm{E}-01$ & $5.3 \mathrm{E}-01$ & $<6.6 \mathrm{E}+00$ & $7.4 E+\infty 0$ & $5.0 \mathrm{E}+00$ & $9.7 \mathrm{E}-01$ \\
\hline $\mathrm{Zr} / \mathbf{E q} . \mathrm{U}$ & $<4.3 \mathrm{E}-01$ & $1.5 \mathrm{E}-01$ & $<1.1 \mathrm{E}+01$ & $3.9 \mathrm{E}-01$ & $<2.1 E+00$ & $3.6 \mathrm{E}-01$ \\
\hline
\end{tabular}


S. D. Fink

December 12, 1996
WSRC-TR-96-0410, rev. 0

Page 22 of 22
T. Monahon, 703-H

V. Dickert, 703-H

B. L. Lewis, 703-H

M. C. Chandler, 703-H

R. L. Boyleston, 706-23C

R. H. Ross, 703-H

J. R. Hester, 703-H

M. E. Jamison, 703-H

G. A. Taylor, 703-H

M. D. Johnson, 704-56H

J. E. Marra, 704-56H

A. W. Wiggins, $241-152 \mathrm{H}$

M. S. Miller, 704-56H

P. L. Rutland, 241-152H

J. N. Brooke, 719-4A

J. A. Pike, 707-H

D. E. Lott, $241-197 \mathrm{H}$

T. K. Bragg, 241-197H

A. L. Blancett, 773-A

$\mathrm{K}$. Andringa, 773-41A

P. L. Cloesner, 773-A

J. C. Griffin, 773-A

C. J. Coleman, 773-A

M. A. Polochko, 773-A.

P. E. Lowe, 773-41A

L. M. Nelson, 773-43A

G. T. Wright, 773-A

L. M. Papauchado, 773-A

W. L. Tamosaitis, 773-A

W. E. Stevens, 773-A

S. D. Fink, 773-A

W. B. Van-Pelt, 676-T

M. C. Thompson, 773-A

D. D. Walker, 773-A

M. J. Barnes, 773-A

M. S. Hay, 773-A

M. Poirier, 676-T

N. E. Bibler, 773-A

B. J. Wiersma, 773-A

W. R. Wilmarth, 773-42A

SRTCILWP Files c/o A. Patterson, 773-A

ITP Files, clo A. Lennay, 241-121H
For for

File Code: 301.0 